This article has been published in a revised form in Enterprise and Society https://doi.org/10.1017/eso.2020.48. This version is published under a Creative Commons CC-BY-NC-ND. No commercial re-distribution or re-use allowed. Derivative works cannot be distributed. (C) The Author(s) 2020. Published by Cambridge University Press on behalf of the Business History Conference.

\title{
For all intents and purposes: Depositor behaviour and strategy in a London savings bank
}

Authors' affiliations:

${ }^{\Delta}$ Linda Perriton, Associate Professor in Human Resource Management, Stirling Management School, University of Stirling, Stirling, FK9 4LA, Scotland, email: linda.perriton@stir.ac.uk

Stuart Henderson, Lecturer in Financial Services, Ulster University Business School, Ulster University, Newtownabbey, BT37 0QB, Northern Ireland, email: s.henderson1@ulster.ac.uk

${ }^{\Delta}$ Corresponding author 


\section{For all intents and purposes: Depositor behaviour and strategy in a London savings bank}

In this paper, we offer an alternative to class-based studies of saving behaviour by using individual-level ledger records from accounts opened in 1830 in the Limehouse Savings Bank, London. Our analysis suggests that such banks banks served a valid financial purpose for a much wider constituency of savers than the targeted 'industrious poor'. True gaming of the system by the middle classes appears to be relatively limited, and instead depositors were using accounts for a variety of means and motivations. We suggest that the contemporary consternation around class was misplaced, and that we can better understand and predict depositor behaviours through analysis of transaction data.

Keywords: Savings Banks, England, Philanthropy, Savings Behaviour.

\section{Introduction}

The birth of British savings banks sparked a contemporaneous debate about the extent to which access to banking could ameliorate the social problems faced by the poor. For the philanthropist, savings banks could aid the working classes by promoting a thrifty consciousness of the future, and thus improve the social security of workers. However, for their critics, savings banks were of limited social efficacy and were instead ripe for exploitation by the middle classes. In England and Wales, the founders of savings banks created them on a 'savings only' model with the ostensible aim of pursuing social welfare outcomes. Savings banks paid interest to savers by using the deposits to purchase government bonds that paid guaranteed interest. In other countries, e.g. Sweden, savings banks generated the funds to pay interest on deposits from the interest they charged on loans. The result of the deposit-only 
model has been to position English and Welsh savings banks within the history of humanitarian institutions, and not productive financialisation. ${ }^{\mathrm{i}}$ As a consequence, the bulk of the literature concerning savings banks does not reside in the fields of economic and financial history but in philanthropy and historical social policy.

The lack of attention by financial historians shown towards the savings behaviour of individuals in 19th century Britain has weakened the social histories of working class financial management, ${ }^{\mathrm{ii}}$ and past studies of its banks. ${ }^{\mathrm{iii}}$ The use of ledger data in the study of savings in the United States is more established ${ }^{\mathrm{iv}}$ and, more recently, there have been studies using transaction data in respect of both Scottish (i.e. Glasgow) and Irish (i.e. Thurles) savings banks. ${ }^{\mathrm{v}}$ The lack of ledger based research is regrettable. Without a body of historical research that uses transaction data, modern debates about savings - including those that discuss savings within a lifecycle or transitional income framework - lack a long-term perspective and fail to put savings behaviour sufficiently in the frame. ${ }^{\mathrm{vi}}$

This paper puts the savers, and their behaviours, at the centre of the analysis. It uses a recently constructed database of 3,625 individual account transactions from the Limehouse Savings Bank in London, which has a long unbroken run of ledger records available. We were able to capture data across the lifespan of all accounts opened in 1830, some of which are held in excess of 40 years. Our 195 new account openers in 1830 comprised 57 adult men, 74 adult women - 33 married, 32 single, and 9 widowed, and 37 children's accounts -19 girls and 18 boys. Seventeen accounts were held jointly, and ten in trust for other individuals - most often children. The accounts opened in 1830 contained 16 family groups; four consisted of related adults, the remaining twelve were either child siblings, or a parent plus child(ren). The assembled database allows us to explore research questions and test propositions that studies, which rely on official 19th century government statistics based on reporting from each bank 
regarding account numbers and total deposits, do not. We are able to link depositor characteristics such as gender, age and marital status with transaction information, and thus identify the potential social determinants of depositor behaviour. Furthermore, by focusing on previously overlooked factors such as opening deposit, proximity, and family group accounts, we can provide insight into the likely strategic intentions of savers. The choice of 1830 , despite the lack of census data for the same period, was in order to take advantage of the 1828 standardisation of record-keeping in English and Welsh savings banks and to have a benchmark year that was still in the period where the banks, and accessible banking, were established.

The paper is structured as follows: in the next section, we establish the historical reporting formats of the savings banks and the reasons why 'class of depositor' tables became an extraofficial category of reporting. The restrictive, and limiting, legacy of that reporting format on subsequent scholarship in relation to savings behaviour is briefly discussed. In the following section, the Limehouse data and collection procedure are outlined, and three hypotheses are proposed. We then examine the social determinants of depositor behaviour, focusing on gender, age and marital status. Following this, we address our three novel hypotheses focusing on the relevance of opening deposit, location and linked accounts in transaction patterns. Finally, the paper concludes by considering the new insight gained from shifting the focus of the analysis from class-of-depositor to individual transaction patterns. Such an approach, we argue, is much more illuminating on the range of valid social and economic functions such banks fulfilled, and crucially provides a more useful benchmark for further comparison with savings institutions in other times and places.

\section{Reporting of occupational class}

Savings banks, as initially conceived of in England and Wales, were a type of financial institution that was formed outside the private and limited joint-stock banking system of the 
period. Savings banks in England and Wales only offered deposit facilities, set limits on the amount that could be deposited annually, and would not extend credit. After 1817, all monies collected by savings banks were deposited with the government in bonds, known as Consols, and used to offset national debt. ${ }^{\text {vii }}$ Consol rates were generous and a near constant source of complaint from critics. The suspicion was that affluent middle-class savers were exploiting banks that were created for the working poor. Parliament saw a number of further attempts by concerned representatives to lower deposit limits and interest rates to reduce the potential for exploitation after the more obvious loopholes were closed in 1828 , but they remained largely as set at the end of the 1820 s throughout the century. Newspapers were also keen to point out the colonisation of the savings banks by the middle class - pointing to the practice of opening accounts for each child in the family and depositing the maximum annual amount or knowingly flouting the law that an individual could not hold more than one account by opening accounts in a number of separate banks. ${ }^{\text {vii }}$

Maltby's paper on the reporting requirements of savings banks in England and Wales outlines the path dependency created by the perceived requirement of savings banks to defend themselves against the charge that they were institutions for the benefit of the monied middle class. ${ }^{\text {ix }}$ She identifies two different categories of reporting. The first set was created by the savings bank legislation itself. All banks had the same year end of November 20th, which was also the date individual account interest was calculated and recorded. Each bank was required to produce an annual report and return, and to have this report approved at an annual meeting of trustees and managers prior to its return to the National Debt Commissioner. The report was to include a statement of the total amounts received and withdrawn from savers in the year, the amount paid to the National Debt Commissioners for investment, and the total of balances held by the bank. The bank was also required to produce a breakdown of the number of depositor accounts in bands from those below $£ 20$ to those above $£ 200 .^{\mathrm{x}}$ 
The second type of reporting was that which the individual banks felt necessary to produce for local stakeholders, including the press, and which sought to present evidence as to the class of depositor the bank had. Unlike the state-mandated reporting categories, the class of depositor reporting by banks differed and was not directly comparable. Maltby provides four examples from banks across the UK and Ireland that showed the different descriptions used of savers in terms of their occupations and social class. ${ }^{\mathrm{xi}}$ The differences are probably representative of the different social mix applicable to the different countries, their local economies and social structure. However, Maltby suggests that the banks in her sample opted not to use the categories included by the parliamentary Select Committee for depositors at the 'higher end' of social standing. Her inference is that the banks did so to shield themselves from criticism that they were not fulfilling their social mission of attracting the poor. ${ }^{\text {xii }}$

Our concern with occupational data is twofold. The occupational data we have for Limehouse accounts opened in 1830 shows that even if an occupation is held in common, motivations to save are not, and neither is the amount of income available to save. Engineers, mariners, shipwrights, and watermen are occupations that appear across all savings categories, and all deposit sizes. And so do married women. That observation leads to our second concern i.e. that it focuses attention - to a greater extent than is justified - on adult male savers. Adult males do not represent the majority of savers in our Limehouse sample and to categorise savers according to occupations in preference to demographic and behavioural characteristics is androcentric. As Folbre notes, ${ }^{\text {xii }}$ the gender bias inherent in definitions of economically productive activity has implications for the analysis of change in labour force participation and, we would argue, financial management.

Nonetheless, as a result of the social concerns about who was using the savings banks, it is class of depositor information, together with the annual reporting of the banks with regards to 
total deposits and standardised bands of account balance, that forms the bulk of the accessible British data available to savings historians. The problem with this data is that it restricts the researcher to a very narrow set of research questions. Existing research, especially in respect of English and Welsh, savings banks therefore tends to focus on who the savers were (according to broad occupational rather than social demographic categories), and the analysis of regional or nationally aggregated account balances.

In terms of surviving historical data, it has also (erroneously) been assumed that there is little extant material regarding working-class savings in English and Welsh banks available, ${ }^{\text {xiv }}$ especially as the account ledgers of the Post Office Savings Banks have not been conserved. A survey of the Trustee Savings Bank material held in the Lloyds TSB Archive in 2015 suggests we are in a more fortunate position than previously thought. The TSB archive holds bank ledgers representing 55 banks, 17 of which have continuous runs of data for 45 years or more. There are individual bank account details from 25 individual banks that show transactions from 1818 , and 19 of those 25 banks have records that cover the entire $1818-1828$ period that was assumed to be missing altogether. ${ }^{\mathrm{xv}}$ Added to the official TSB holdings are those additional historical bank records held in county, city and district archives - all of which represent a rich resource for examining 19th century savings behaviour.

Ledger data has been used in savings bank research in the US and, more recently, has also been sampled in relation to a Scottish savings bank to establish the response of savers to financial crises in 1847 and $1857 .{ }^{x v i}$ Payne also used transaction data for Glasgow, but in a limited way. ${ }^{\text {xvii }}$ Although time-consuming and labour-intensive, the benefits of looking at transactionlevel data is obvious. For example, Perriton and Maltby's study of transaction patterns at four English savings banks was able to challenge long-standing assumptions about the conflictual nature of working-class financial management within marriage by looking at the number of 
married women accounts and the broad use patterns revealed by deposit-to-withdrawal ratios. ${ }^{\text {xviii }}$ Studies using transaction data - even at a meta-level to allocate accounts to categories - create a richer picture of historical savings behaviour.

We wanted to fully exploit the ledger data we have available by creating a database for all accounts opened in the calendar year 1830 in the savings bank in Limehouse, London in order to look beyond occupational class analysis. The Limehouse Savings Bank (created as the Limehouse Provident Institution for Savings in 1816) was typical of the type of savings bank that survived into the 20th century because it served a diverse, urban population. The district of Limehouse is approximately two miles east of the medieval London Docks next to the Tower of London and formed the industrial and manufacturing hinterland to the east of the city. The East End of London, as the area is known generically, is situated at the junction of the road transport routes into the site of the 'new' docks on the Isle of Dogs peninsula in the Thames and the older road routes out of the city towards the Essex coast. As a result of the growing transport infrastructure around the docks in the 19th century, the rapidly increasing population of Limehouse and its surrounding parishes specialised in trade and small manufacturing. ${ }^{\text {xix }}$

\section{Limehouse - data and hypotheses}

To explore the transaction patterns of individual savers, we accessed the individual account records of the Limehouse Savings Bank, extant in the year range 1828-1876, to examine the savings behaviour of a cohort of savers who opened accounts in 1830 . The sample year of 1830 was chosen as it represented a point at which savings bank record-keeping and reporting was standardised, and where the accounts opened would be operating under the reforms of 1828 i.e. maximum annual deposits and maximum account limits. John Tidd Pratt, the barrister advising the Commission for the Reduction of Public Debt, and Registrar of Friendly Societies, also published his 'History of the Savings Banks in England, Wales and Ireland' in $1830 .{ }^{\mathrm{xx}}$ 
This report contains a useful summary of the savings banks in existence at that date, including their total reported depositors and average account balances. Similar summaries and returns would be published in subsequent years by parliament. However, 1830 also marked the end of an unstable period of Conservative government that had introduced the savings bank legislation and the start of parliamentary reforms. This included a debate as to whether savings bank balances could be used as the basis of suffrage. Clearly, by 1830, savings banks were an established part of the social landscape and had won acceptance, albeit often partial and grudging, across the political divide.

The 1830 sample comprises 195 new saver accounts, and a total of 3,625 individual transactions. Each account was given a unique identifier number and the following were recorded: name(s) of account holder(s), residential address at account opening, occupation or status of the account holder(s), a note of whether the account was held individually, jointly, or in trust, and any margin notes or interesting features of the account. Joint accounts are accounts that have two or more named account holders. Trust accounts are accounts opened by an individual 'in trust' for a third party. Trust accounts have a named trustee, who is listed first and then the words 'in trust for' appear before the second name. Every individual account transaction (deposit, withdrawal, interest payment) was recorded over the life of each account together with the date the transaction occurred. Where accounts were closed and re-opened at a later date, we have noted the years of closure but treat the account duration as being from the first deposit to the last withdrawal. ${ }^{\mathrm{xx}}$

For the analysis, we amalgamated the depositor and transaction data to generate a spreadsheet of aggregate statistics by depositor. By identifying savers' residential addresses on a map of Limehouse in $1851,{ }^{\text {xii }}$ we were also able to consider the relevance of proximity to the bank in depositor behaviour. In addition, we supplemented the ledger data with English census data 
(1841-1891) and data from the index of births, deaths and marriages. This enabled us to establish approximate birth years of a small sub-sample of savers, which we use as illustrative cases.

\section{Hypotheses}

Using the Limehouse data, we aim to address three hypotheses which will provide a different perspective on the functionality of British savings banks and move the debate beyond the existing class-of-depositor perspective. These three hypotheses are now outlined.

\section{Hypothesis 1: Opening deposit predicts subsequent depositor behaviour}

Opening deposit data has been used infrequently in savings bank research, and even less often in relation to the analysis of subsequent saver behaviour. Alter, Goldin and Rotella's paper on the Philadelphia Savings Fund includes opening deposits as a category of analysis in examining the duration of accounts. ${ }^{\text {xiii }}$ However, as the median opening deposit is consistent across sample, it is not a significant factor in their analysis. Pollock also notes the median and lower and upper quartile of opening deposits in his study of the Glasgow Savings Bank. ${ }^{\text {xiv }}$ However, like the inclusion of the figure in the Philadelphia study, the opening deposit is merely noted in Pollock's study rather than used in analysis. Given the emphasis on who saved in many studies, it is often the maximum balance held that is deemed to be of greater significance.

Yet the size of the opening deposit often vexed the critics of English and Welsh savings banks. Savers were restricted to a total of $£ 30$ in deposits per annum. Those who deposited the whole $£ 30$ upon opening an account in their own name - or via a trust, or across a number of family members' accounts - were suspected of taking advantage of savings bank provision. ${ }^{\mathrm{xxv}}$ Transaction data allows us to categorise accounts using the opening deposit, and to look closely at those accounts that caused consternation at the time i.e. those opened with $£ 30$. Unlike the Philadelphia study, which reported a consistent opening deposit of circa $\$ 50$, Limehouse has a 
much wider spread of opening deposits from small to the maximum and has greater salience in this study as an analytical category.

\section{Hypothesis 2: Depositor location affects behaviour}

At the time of the introduction of the Post Office Savings Bank in 1861, it was noted that much of the population did not have a local savings bank - 15 counties had no provision at all, and many populous towns also lacked one. ${ }^{\mathrm{xxvi}}$ The reliance on volunteer trustees to oversee the operation of the bank, and to be present during opening hours, limited the times that they were open. Limited opening times were therefore identified as a barrier to creating a regular savings habit - unless you lived in close proximity to a bank. The importance of proximity in encouraging savings behaviour has been a feature of recommendations in relation to increasing savings in the general population from the late 19th century to present day. Microfinance institutions, especially those that cater to the rural poor in developing countries focus on proximity as one of their main priorities. Although there is no single measure that captures the determinants of saving in an institution, meta-analyses have established that locational convenience (i.e. distance covered to deposit and withdraw), low transaction costs, simplicity of transactions, ability to deposit small amounts, and convenience of service hours, are all positive indicators. ${ }^{x x v i i}$ We anticipate being able to discern differential patterns of savings behaviour based on residential location and distance from the Limehouse Savings Bank.

\section{Hypothesis 3: Gaming of savings bank account holding existed, but was minimal}

The potential for misuse of the savings banks, as noted above, was a concern of fiscal conservatives in government throughout the first half of the 19th century. Misuse in this context covered two main areas i.e. multiple account holding, and profit-seeking from middle-class depositors who were taking advantage of subsidised interest payments intended for the poor. Fishlow contends that the regulatory changes of 1828 , which created a balance ceiling of $£ 200$, 
together with an annual maximum deposit limit of $£ 30$, and the disallowed practice of multiple account holding effectively saw the end of systematic exploitation of the savings banks by the wealthy. ${ }^{x x v i i i} \mathrm{He}$ points to the substantial reduction in accounts and deposits after the introduction of the 1828 regulations. There was still potential for masking multiple account. Individuals could do so by opening accounts in children's names but operating them as their own, banking in a neighbouring or distant bank in addition to holding an account their local bank and not disclosing it, and/ or by using trust accounts opened in the name of individuals unaware of the account or the transactions undertaken in their name.

Fishlow made the point that given the English joint-stock banks did not provide opportunities for those with modest cash surpluses it was reasonable to conclude that English savings banks would attract a greater number of middle-class accounts than was the case elsewhere. ${ }^{\text {xix }} \mathrm{We}$ accept Fishlow's point. We do not see the existence of higher-balance accounts, or certain occupations amongst the depositors, as evidence of gaming of the savings bank system per se. We do, however, believe that transaction data will be able to identify 'problematic' accounts from the 19th century perspective. Perriton suggested that the 'strategic' use of Limehouse trust accounts after 1844, the date in which changes were made to the regulations concerning such accounts, was circa 5\%. ${ }^{\mathrm{xx}}$ Because trust accounts were an unreformed feature of the system in 1830 , we anticipate a higher rate of accounts that are potentially gaming the post1828 rules by exploiting trusts, but that the incidence of such accounts will be minimal.

\section{Summary statistics}

Before addressing our hypotheses, we first present some summary statistics relating to the demographic and transaction characteristics of our dataset.

\section{Individual accounts}


Table 1 shows the basic composition of our sample. In the individual depositor categories, there is a majority of female depositors (55\%) to male depositors (45\%). Most of the individual accounts $(67 \%)$ are held by adults, although there is a significant minority of children. The sizeable proportion of children is plausible - children were financially active either by their involvement in penny capitalism ${ }^{\mathrm{xxxi}}$ or when in receipt of monetary gifts. An emphasis on thrift amongst the middle classes also makes the number of child accounts opened unsurprising and may reflect a prevailing social norm in the instruction of children on the benefits of saving. Nevertheless, statistics presented later in the paper do question whether some child accounts were being operated independently of those held by their parents.

Table 1. Frequency of accounts

\begin{tabular}{lcc}
\hline \hline & Frequency & \% of total \\
\hline Adult male & 57 & 29.23 \\
Adult female & 74 & 37.95 \\
$\quad$ Widow & 9 & 4.62 \\
$\quad$ Married & 33 & 16.92 \\
$\quad$ Single & 32 & 16.41 \\
Child male & 18 & 9.23 \\
Child female & 19 & 9.74 \\
Joint & 17 & 8.72 \\
Trust & 10 & 5.13 \\
\hline Total & 195 & \\
\hline \hline
\end{tabular}

\section{Non-individual accounts}

Non-individual accounts opened in Limehouse in 1830 are either joint (9\%) or trust accounts (5\%). Joint accounts are accounts that have two or more named account holders. In many cases the named individuals share a family name, but there are examples where this is not the case and/or cases where there is an additional margin note that 'any two to sign'. Trust accounts are accounts opened by an individual 'in trust' for a third party. In the majority of cases, where a trust account is recorded the named trustee does not share the family name of the individual 
the account is held in trust for - just four out of the eleven trust accounts are held for another (child or infant) family member. For example, Ruth Noble holds accounts in trust for Eleanor Walford and Hannah Packer, and Mary Ann Whitehead is trustee for a servant, Mary Ring, for a scant six months before she takes full control of her own account and runs it independently for the next three years. There is also an example of an account held in trust for a widow by an individual male, who is not listed amongst the heirs to her estate (and passbook), and which we presume is a solicitor or some other legal representative.

\section{Transaction statistics}

\section{Adults}

Table 2 shows the number and size of depositor transactions according to our main demographic categories. ${ }^{\text {xxii }}$ On average, adult males make larger deposits and larger withdrawals than adult females. Furthermore, among both adults and children, males tend to make more transactions than females, with adult males noticeably transaction-heavy relative to others.

Table 2. Number and size of transactions

\begin{tabular}{lrrrrrr}
\hline \hline & Mean & Median & Std. dev. & Min & Max & Obs. \\
\hline Number of deposits & & & & & & \\
All & 7.56 & 3.00 & 14.90 & 1.00 & 130.00 & 195 \\
Adult male & 7.95 & 4.00 & 10.77 & 1.00 & 47.00 & 57 \\
Adult female & 6.30 & 2.50 & 9.72 & 1.00 & 66.00 & 74 \\
$\quad$ Widow & 4.44 & 2.00 & 5.32 & 1.00 & 16.00 & 9 \\
$\quad$ Married & 9.36 & 5.00 & 13.34 & 1.00 & 66.00 & 33 \\
$\quad$ Single & 3.66 & 1.50 & 3.65 & 1.00 & 15.00 & 32 \\
Child male & 16.89 & 2.00 & 38.88 & 1.00 & 130.00 & 18 \\
Child female & 4.89 & 2.00 & 5.02 & 1.00 & 15.00 & 19 \\
Joint & 6.35 & 3.00 & 9.47 & 1.00 & 39.00 & 17 \\
Trust & 5.10 & 3.50 & 4.53 & 1.00 & 14.00 & 10 \\
& & & & & & \\
Average deposit & & & & & & \\
All & $£ 1015 \mathrm{~s} 8 \mathrm{~d}$ & $£ 76 \mathrm{~s} 8 \mathrm{~d}$ & $£ 103 \mathrm{~s} 8 \mathrm{~d}$ & $£ 01 \mathrm{~s} 0 \mathrm{~d}$ & $£ 308 \mathrm{~s} 9 \mathrm{~d}$ & 195 \\
Adult male & $£ 125 \mathrm{~s} 3 \mathrm{~d}$ & $£ 8$ 1s 6d & $£ 919 \mathrm{~s} \mathrm{11d}$ & $£ 03 \mathrm{~s} 0 \mathrm{~d}$ & $£ 308 \mathrm{~s} 9 \mathrm{~d}$ & 57
\end{tabular}




\begin{tabular}{|c|c|c|c|c|c|c|}
\hline Adult female & $£ 94 \mathrm{~s} 2 \mathrm{~d}$ & $£ 610 \mathrm{~s} 5 \mathrm{~d}$ & $£ 96 \mathrm{~s} 7 \mathrm{~d}$ & $£ 01 \mathrm{~s} 6 \mathrm{~d}$ & $£ 300 \mathrm{~s} 0 \mathrm{~d}$ & 74 \\
\hline Widow & $£ 130 \mathrm{~s} 6 \mathrm{~d}$ & $£ 116 \mathrm{~s} 8 \mathrm{~d}$ & $£ 119 \mathrm{~s} 2 \mathrm{~d}$ & $£ 10$ s $0 \mathrm{~d}$ & $£ 30$ 0s 0d & 9 \\
\hline Married & $£ 1013 \mathrm{~s} 7 \mathrm{~d}$ & $£ 80 \mathrm{~s} 0 \mathrm{~d}$ & $£ 105 \mathrm{~s} 5 \mathrm{~d}$ & $£ 01 \mathrm{~s} 6 \mathrm{~d}$ & $£ 300 \mathrm{~s} 0 \mathrm{~d}$ & 33 \\
\hline Single & $£ 612 \mathrm{~s} 5 \mathrm{~d}$ & $£ 313 \mathrm{~s} 0 \mathrm{~d}$ & $£ 6$ 19s 6d & $£ 02 \mathrm{~s} 6 \mathrm{~d}$ & $£ 30$ 0s $0 \mathrm{~d}$ & 32 \\
\hline Child male & $£ 108 \mathrm{~s} 2 \mathrm{~d}$ & $£ 28 \mathrm{~s} 5 \mathrm{~d}$ & $£ 1212 \mathrm{~s} 0 \mathrm{~d}$ & $£ 02 \mathrm{~s} 0 \mathrm{~d}$ & $£ 300 \mathrm{~s} 0 \mathrm{~d}$ & 18 \\
\hline Child female & $£ 108 \mathrm{~s} 3 \mathrm{~d}$ & $£ 215$ s $11 d$ & $£ 1215 \mathrm{~s} 2 \mathrm{~d}$ & $£ 01 \mathrm{~s} 0 \mathrm{~d}$ & $£ 30$ 0s 0d & 19 \\
\hline Joint & $£ 147 \mathrm{~s} 9 \mathrm{~d}$ & $£ 11$ 8s $11 \mathrm{~d}$ & $£ 914 \mathrm{~s} 1 \mathrm{~d}$ & $£ 215 \mathrm{~s} 0 \mathrm{~d}$ & $£ 300 \mathrm{~s} 0 \mathrm{~d}$ & 17 \\
\hline Trust & $£ 95 \mathrm{~s} 3 \mathrm{~d}$ & $£ 717$ s $5 d$ & $£ 76 \mathrm{~s} 6 \mathrm{~d}$ & $£ 112 \mathrm{~s} 10 \mathrm{~d}$ & $£ 22$ 11s 3d & 10 \\
\hline \multicolumn{7}{|c|}{ Number of withdrawals } \\
\hline All & 5.23 & 2.00 & 7.29 & 0.00 & 37.00 & 195 \\
\hline Adult male & 6.05 & 3.00 & 8.21 & 1.00 & 37.00 & 57 \\
\hline Adult female & 4.55 & 2.00 & 6.05 & 0.00 & 34.00 & 74 \\
\hline Widow & 5.56 & 4.00 & 4.75 & 1.00 & 13.00 & 9 \\
\hline Married & 6.36 & 4.00 & 7.68 & 1.00 & 34.00 & 33 \\
\hline Single & 2.41 & 1.00 & 3.30 & 0.00 & 18.00 & 32 \\
\hline Child male & 5.94 & 2.00 & 9.20 & 1.00 & 34.00 & 18 \\
\hline Child female & 1.68 & 1.00 & 1.45 & 1.00 & 6.00 & 19 \\
\hline Joint & 8.59 & 5.00 & 9.15 & 1.00 & 31.00 & 17 \\
\hline Trust & 5.20 & 2.00 & 7.70 & 1.00 & 26.00 & 10 \\
\hline \multicolumn{7}{|c|}{ Average withdrawal } \\
\hline All & $£ 154 \mathrm{~s} 2 \mathrm{~d}$ & $£ 811 \mathrm{~s} 2 \mathrm{~d}$ & $£ 181 \mathrm{~s} 7 \mathrm{~d}$ & $£ 01 \mathrm{~s} 0 \mathrm{~d}$ & $£ 936 \mathrm{~s} 1 \mathrm{~d}$ & 194 \\
\hline Adult male & $£ 18$ 5s 4d & $£ 12$ ss $4 d$ & $£ 1713 \mathrm{~s} 4 \mathrm{~d}$ & $£ 03 \mathrm{~s} 0 \mathrm{~d}$ & $£ 90$ 0s $3 \mathrm{~d}$ & 57 \\
\hline Adult female & $£ 138 \mathrm{~s} 9 \mathrm{~d}$ & $£ 514 \mathrm{~s} 2 \mathrm{~d}$ & $£ 1718 \mathrm{~s} 10 \mathrm{~d}$ & $£ 01 \mathrm{~s} 6 \mathrm{~d}$ & $£ 936 \mathrm{~s} 1 \mathrm{~d}$ & 73 \\
\hline Widow & $£ 10$ 7s $1 \mathrm{~d}$ & $£ 917 \mathrm{~s} 10 \mathrm{~d}$ & $£ 102 \mathrm{~s} 5 \mathrm{~d}$ & $£ 10 \mathrm{~s} 9 \mathrm{~d}$ & $£ 315 \mathrm{~s} 3 \mathrm{~d}$ & 9 \\
\hline Married & $£ 14$ 15s 9d & $£ 46 \mathrm{~s} 2 \mathrm{~d}$ & $£ 18$ 4s 5d & $£ 01 \mathrm{~s} 6 \mathrm{~d}$ & $£ 62$ 1s $5 \mathrm{~d}$ & 33 \\
\hline Single & $£ 12$ 18s 0d & $£ 514 \mathrm{~s} 2 \mathrm{~d}$ & $£ 19$ 13s 0d & $£ 02 \mathrm{~s} 6 \mathrm{~d}$ & $£ 936 \mathrm{~s} 1 \mathrm{~d}$ & 31 \\
\hline Child male & $£ 811$ s $0 d$ & $£ 412 \mathrm{~s} 9 \mathrm{~d}$ & $£ 813 \mathrm{~s} 3 \mathrm{~d}$ & $£ 08 \mathrm{~s} 0 \mathrm{~d}$ & $£ 3010 \mathrm{~s} 0 \mathrm{~d}$ & 18 \\
\hline Child female & $£ 1514 \mathrm{~s} 8 \mathrm{~d}$ & $£ 1512 \mathrm{~s} 6 \mathrm{~d}$ & $£ 1217 \mathrm{~s} 6 \mathrm{~d}$ & $£ 01 \mathrm{~s} 0 \mathrm{~d}$ & $£ 3013$ s $4 d$ & 19 \\
\hline Joint & $£ 15$ 17s 11d & $£ 72$ s $11 \mathrm{~d}$ & $£ 2311 \mathrm{~s} 4 \mathrm{~d}$ & $£ 019 \mathrm{~s} 8 \mathrm{~d}$ & $£ 848 s$.d & 17 \\
\hline Trust & $£ 2010 \mathrm{~s} 4 \mathrm{~d}$ & $£ 710 \mathrm{~s} 6 \mathrm{~d}$ & $£ 2814 \mathrm{~s} 11 \mathrm{~d}$ & $£ 22 \mathrm{~s} 8 \mathrm{~d}$ & $£ 925 \mathrm{~s} 4 \mathrm{~d}$ & 10 \\
\hline
\end{tabular}

There are also pronounced differences between adult women's savings behaviour when we subdivide the adult females into widow, married and single categories. ${ }^{\text {xxxiii }}$ The widows in our sample tend to make a large opening deposit, then undertake multiple withdrawals, either to zero or a very small sum at account closure. This pattern can easily be made to fit a typical scenario where the widow opens an account with the inheritance from their deceased spouse and that they then run that balance down in living expenses. However, that assumption is not borne out in the savers we have been able to trace through census and birth, death and marriage data. For example, Margaret Leslie, a widow of 2 New Crane Place, Shadwell, does open her 
account relatively soon after her husband's death. But Margaret is a small saver in terms of opening deposit (£2), and although she accumulates steadily for the next three years, she then enters an active period of deposits and withdrawals until 1838, and then only draws down on the account until the account closes in 1845. Margaret dies in 1870, so we cannot assume the period of draw down is in anticipation of her death or last serious illness. Another widow in our sample, Sarah Hornzee, ${ }^{\text {xxiv }}$ opens her account with the maximum annual deposit of $£ 30$, but she opens her account at 56 years of age, and six years after the death of her husband. She makes one further deposit of $£ 30$ before commencing a period of drawing down from the account over the next four years. Again, this period does not correspond to her own decline as she dies in 1842 - eight years after the account is closed.

Single women, on average, tend to hold their accounts for relatively short periods of time, have a low number of transactions overall, and deposit the least among adult women. However, relative to their opening balance they close their accounts at a relatively high level - their median closing balance (approx. $£ 9$ ) is over twice their median opening balance (approx. $£ 4$ ). Taken together, this suggests a pattern of lower amounts available for saving, less frequent deposits, and the situation where the money is kept until needed for transfer elsewhere (perhaps to follow domestic employment), or for a definite purpose - also a finding of the Philadelphia Savings Fund study. ${ }^{\mathrm{xxxv}}$

Married women tend to deposit significantly more money than single women, and also make more deposits and withdrawals. We agree with Perriton and Maltby in finding the number of accounts held by married women difficult to reconcile with a patriarchal, and controlling, model of working-class financial management. The number of joint married accounts, and intra-family accounts, is indicative of a more egalitarian model of joint decision making on how to save pecuniary surplus. ${ }^{\text {xxvi }}$ 


\section{Children}

The account activity of children is one of the most confusing in the data. There is a large difference between the median and mean for both the opening and average deposit. Ironically, it is the children who do learn the lesson of thrift that may be the root cause of some of these differences. For example, Richard Hinderwell, is a newborn child when an account is opened for him in 1830 with 15s. He becomes an active saver into adulthood - depositing a total of $£ 14$ 17s over the next 43 years and (probably) beyond given that his account is still open at the end of the extant ledgers. His case reflects one of the two extremes of savers in this category, the other extreme being those children who are not aware of holding an account opened and operated by a parent.

Some children show little evidence for having learned the lessons of thrift in childhood but nonetheless become savers as adults. One such individual, Margaret Vesper, has an account opened for her aged 10 with an opening deposit of $17 \mathrm{~s}$. A further deposit of $13 \mathrm{~s}$ is added in the same year but after that point the account is untouched until 1842, a year prior to her marriage when she makes her first adult deposit of $£ 1$ 8s. However, the year after her marriage her account appears to be used as a marital savings account. Over a period of 18 months, the account balance reaches $£ 23$ and is then steadily withdrawn from in the next 12 months until it is closed.

\section{Joint and trust accounts}

Joint accounts were not a feature of all savings banks, but trust accounts were. Banks that served a diverse urban community e.g. Limehouse and Newcastle, were more amenable to nonstandard account types than were the smaller, regional banks such as Bury. ${ }^{\text {xxxvii }}$ The trustees of the urban banks seemed to take the view that if a type of account was not explicitly prohibited 
then they would allow it. As a result, we see joint accounts between two or more individuals representing different generations of the same family, work colleagues, and married couples.

In relative terms, joint accounts and trust accounts are held for significantly longer periods of time than individual accounts (a mean of nine and eleven years respectively). Joint married accounts are active accounts, suggestive of a cycle of building up of pooled financial resources and then deploying cover for unexpected expenditure. Joint accounts have the highest mean deposit at $£ 147 \mathrm{~s} 9 \mathrm{~d}$ (approximately $£ 4$ above the average for all accounts), and the most withdrawals. This is highly suggestive of the use of joint accounts to smooth the demands on domestic expenditure.

Typical of the trend for joint accounts to be held over a longer period of time is the account of Christopher and Margaret Morris, of 18 Farmer Street, Shadwell. Christopher, a shipwright, and Margaret Morris open a joint married account in 1830 with $£ 10$. The age of Christopher is unknown, but Margaret is 27 at the time. This is a long-term account for the couple lasting 30 years and the account activity falls broadly into two patterns. In the first 15 years of the account it is - for the most part - an accumulating account although there are occasional withdrawals alongside the deposits. After 1847, the account functions as a draw down account, with a steady depletion of the account - significant in the first seven years in terms of totals but then slowing in the last seven. The only deposit that is made in the period 1846-1860 is $£ 7$ deposited in the year of Christopher's death in 1857 - suggestive of a small inheritance from him being deposited in the account. The account is closed nine years prior to Margaret's own death.

In this period - and until the regulations were tightened in 1844 - trust accounts are more suspect in terms of potential for evading the prohibition regarding multiple account holding. However, in the summary statistics, apart from a higher deposit-to-withdrawal ratio and the 
relatively long account duration, there are no striking differences between trust accounts and the "average" account.

\section{Opening deposit and subsequent behaviour}

Savings banks in England and Wales in this period accepted deposits as low as 1s to a maximum of $£ 30$. The $£ 30$ figure was the maximum that could be deposited annually, but there was no bar to using that allowance in a single or first deposit. The result, in our Limehouse sample, is of a relatively wide spread of opening deposit amounts (see Figure 1 below). The data contains noticeable clusters at both ends of the deposit amount continuum. ${ }^{\mathrm{xx} x \mathrm{iii}}$

Figure 1. Frequency of opening balances

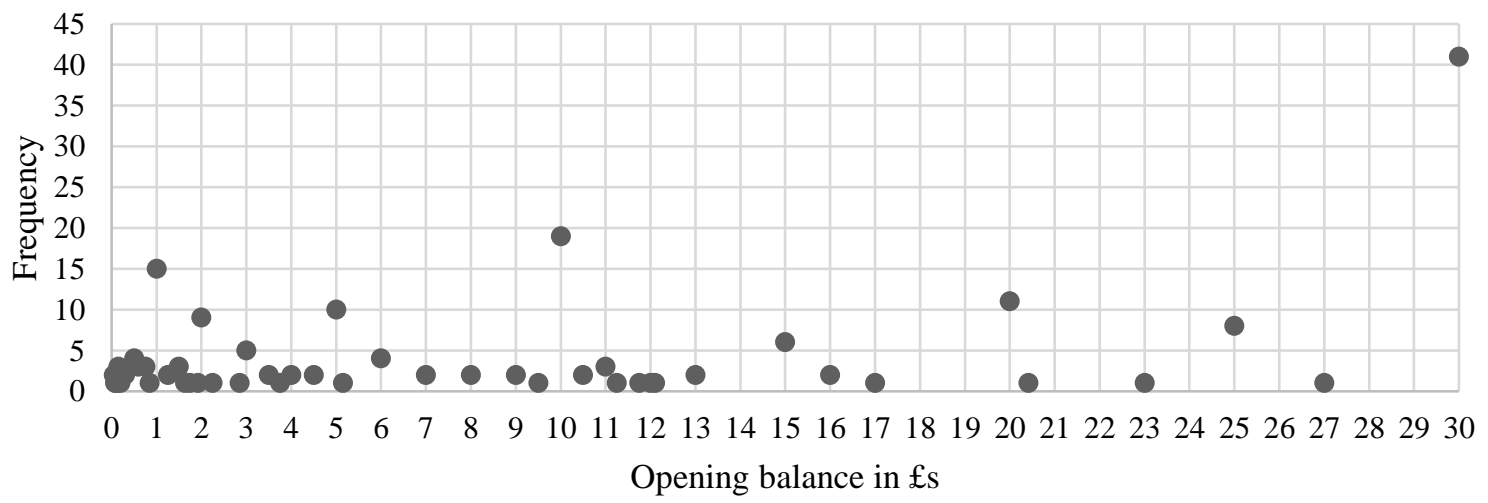

Notes: We have not included the one exception of an account opened with $£ 60$.

For the purpose of further comparison, we will divide our savers into three groups according to their account balance, which we have displayed as follows: $£ 2$ or less (small savers), between $£ 2$ and $£ 30$ (intermediate depositors), and $£ 30$ ( $\max$ depositors).. At the upper end, approximately 22 per cent of our cohort opened their accounts at the maximum balance of £30. ${ }^{\text {xxix }}$ This provides a natural sub-group, since those depositing the maximum balance are considered more suspect in terms of their use of the bank. At the lower end, we choose $£ 2$ as the small saver maximum deposit. This also seems a natural sub-group as around 50 per cent 
of savers deposit between $£ 2$ and $£ 30$, leaving approximately 29 per cent classified as small savers. $^{\mathrm{xl}}$

Our hypothesis is that opening deposit is an indicator of subsequent depositor behaviour. Our further assumption is that those who open an account with a small amount of money are primarily seeking an opportunity to save. However, the capacity to accumulate further savings, at least for the next 12 months, is denied for those who open their accounts with the $£ 30$ maximum. If these accounts were genuine savings accounts - as opposed to a holding or storing account - then we would expect to see them held over a longer period of time, and to be held until the maximum interest-bearing balance is reached. A shorter time period or a pattern of harvesting the interest payments on the balance would suggest that the objective of the $£ 30$ was to have ready access to liquid assets, a bonus in terms of interest generation (albeit of relatively small amounts relative to the capital committed to produce it), and secure storage.

Table 3 shows the transaction differences between the account holders according to the three opening deposit categories: $£ 2$ or less (small savers), between $£ 2$ and $£ 30$ (intermediate depositors), and $£ 30$ (max depositors).

Table 3. Depositor behaviour by opening deposit category

\begin{tabular}{lccc}
\hline \hline & $£ 2$ or less & Betw. $£ 2$ and $£ 30$ & $£ 30$ (or more) \\
\hline Percentage of savers & $28.72 \%$ & $49.74 \%$ & $21.54 \%$ \\
Average deposit* & $£ 15 \mathrm{~s} 11 \mathrm{~d}$ & $£ 919 \mathrm{~s} 4 \mathrm{~d}$ & $£ 256 \mathrm{~s} 4 \mathrm{~d}$ \\
Average withdrawal & $£ 42 \mathrm{~s} \mathrm{6d}$ & $£ 175 \mathrm{~s} 3 \mathrm{~d}$ & $£ 2419 \mathrm{~s} 8 \mathrm{~s}$ \\
Total deposited & $£ 187 \mathrm{~s} 1 \mathrm{~d}$ & $£ 519 \mathrm{~s} 0 \mathrm{~d}$ & $£ 6116 \mathrm{~s} 4 \mathrm{~d}$ \\
Number of deposits & 11.66 & 7.02 & 3.36 \\
Number of withdrawals & 4.80 & 5.75 & 4.57 \\
Ratio of deposits to withdrawals & 3.10 & 1.95 & 1.07 \\
Account duration & 4.47 years & 6.18 years & 4.51 years \\
Accumulating & $30.91 \%$ & $19.59 \%$ & $4.76 \%$ \\
Contingency & $43.64 \%$ & $49.48 \%$ & $40.48 \%$ \\
Draw down & $0.00 \%$ & $16.49 \%$ & $19.05 \%$ \\
In and out & $25.45 \%$ & $14.43 \%$ & $35.71 \%$ \\
\hline \hline
\end{tabular}

Note: The percentage of savers relates to the 195 savers. Non-percentage figures are means. $(*$ Average deposit is the total deposited / number of deposits. This is calculated for each saver. The figure in the table is the mean of all these individual saver statistics.) For some of the statistics above, there are not 195 observations (e.g. where an account was not closed). In the 
case of the four account types - accumulating, contingency, draw down and in and out - there is one account with just one deposit and therefore does not fit this classification.

The transaction averages reveal clear differences between the three groups of savers based on opening deposit amount. Small savers continue to make comparatively small deposits and withdrawals once they open with their modest amount. They also make a considerably higher number of deposits over the life of their account and have a noticeably high ratio of deposits to withdrawals (approximately 3 deposits to every one withdrawal). In relative terms, they are the most successful savers in terms of total deposited held relative to their opening balance. Indeed, the behaviour most often observed in this group is of savers steadily building up their account with small deposits over time and then withdrawing a large amount(s) - presumably to cover planned or necessary one-off expenditure.

In contrast, as a group, the $£ 30$ depositors make the least deposits and withdrawals over the life of their accounts. Those who open their accounts with the maximum permitted tend to make much larger value deposits and withdrawals over the life of their account, but they accumulate the least in relative terms. In max deposit accounts, we witness very short-term and relatively insignificant profit taking (withdrawing the $£ 30$ principal, and - at best - a single full year's interest payment of $15 \mathrm{~s}$, but often less than that amount), or the desire to hold a relatively modest amount of surplus cash, available at short notice, on a recurring annual basis. The failure of $£ 30$ opening deposit accounts to accumulate further significant savings in time supports an interpretation of individuals seeking a secure storage option over a pure profit making/taking strategy. ${ }^{\text {xli }}$

Table 3 shows the classification of account types using Perriton and Maltby's classification system. ${ }^{\text {xlii }}$ Their system is useful as it allocates accounts to one of four types based on the overall pattern of the account. The identifying criteria are as follows: (i) accumulating - the 
account has multiple deposits and then a lump sum withdrawal, (ii) contingency - the account has both deposits and withdrawals, (iii) draw down - the account has a single lump sum deposit that is depleted by multiple withdrawals, and (iv) in and out - the account has only one deposit and one withdrawal. One could argue that this classification system oversimplifies depositor behaviour. Indeed, depositor behaviour may even be dictated by different motivations at different times. However, as a general indicator of behaviour the classification system enables us to usefully combine accounts for comparison purpose. Table 3 shows that contingency accounts represent the largest proportion of accounts regardless of opening balance - over 40 per cent in each opening band. For accumulating accounts, where deposits are built up before a lump sum is withdrawn, the incidence among small savers is particularly pronounced, suggesting they are aggregating their deposits in anticipation of a future need. By contrast, for draw down accounts small savers are completely lacking - which may reflect their small initial investment and related scope for depletion. At the other extreme, max depositors have a particularly high incidence of in and out accounts and lack representation in the accumulating category. This, again, suggests that such depositors are using the bank as a safe storage facility for their funds that has the benefit of interest added, rather than building up deposits over time.

Figure 2 shows how the opening transaction amount relates to gender, age, and marital status (women only). 
Figure 2. Percentage of depositors in each opening balance category

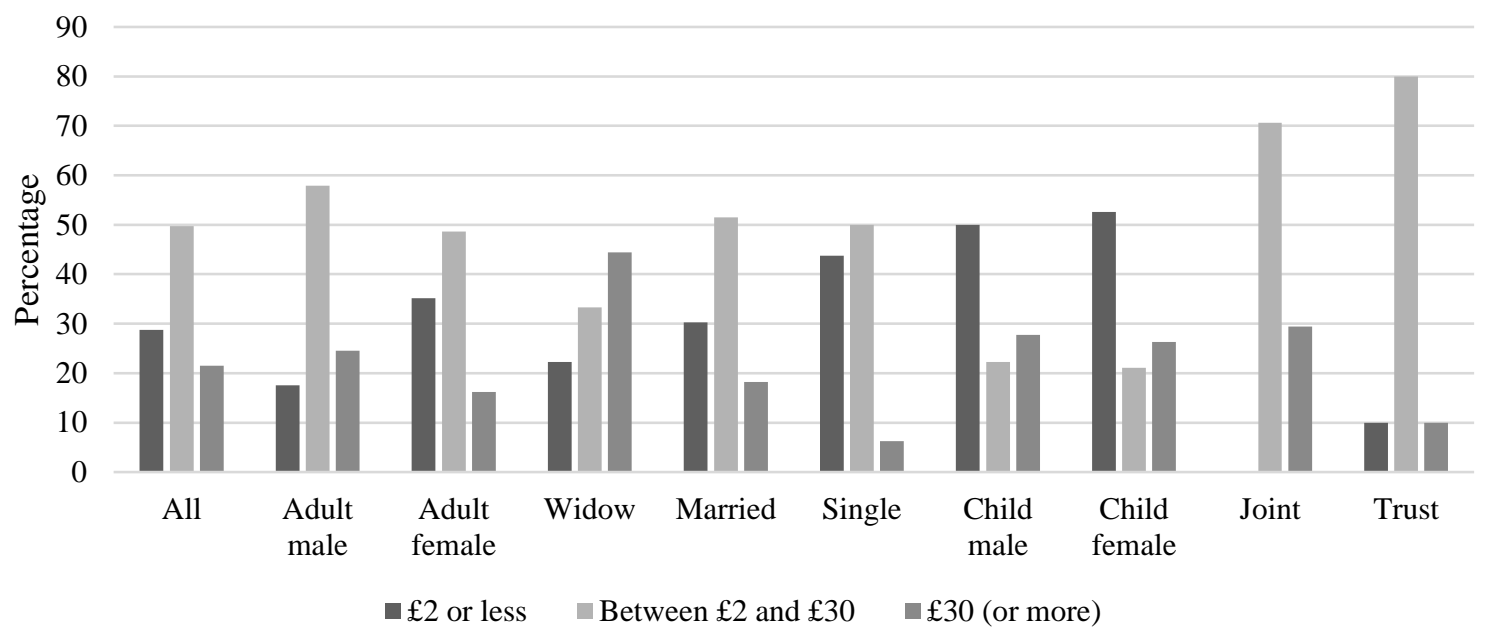

Figure 2 shows that children have the highest proportion of small opening balance accounts, which we might expect given that they are not likely to be regular earners and are perhaps receiving deposit amounts as gifts. However, they are also over-represented, relative to their total account holdings, in the $£ 30$ opening deposit category. The latter gives some credence to the belief that some child accounts were used by adults to get round deposit ceilings and/or the restriction on holding multiple accounts. ${ }^{\text {xliii }}$ Among adults, women open a higher proportion of small accounts than their male counterparts, with single women over-represented in this lower range. Single women lack significant representation in the maximum deposit category. The disaggregation of the adult women accounts shows the anomalous position of widows among the adult women sample, as widows alone are represented in increasing percentages as the opening balances increase. Joint and trust accounts tend not to have small opening balances; instead they are opened with amounts predominantly in the intermediate category.

\section{Depositor location and behaviour}

To consider the impact of distance on savings behaviour, we allocate depositors to various groups according to how far their residential addresses are from the bank: within a half mile radius $(55 \%)$, between half a mile and one mile away (25\%), over one mile away (14\%), or 
outside the map area (6\%). ${ }^{\text {liv }}$ This enables us to consider the impact of distance on behaviour.

Table 4 presents summary statistics disaggregated by distance.

Table 4. Depositor behaviour by distance

\begin{tabular}{|c|c|c|c|c|}
\hline & $<0.5$ mile & 0.5 to 1 mile & $>1$ mile & Outside map \\
\hline Opened at max. balance & $20.56 \%$ & $27.08 \%$ & $21.43 \%$ & $9.09 \%$ \\
\hline Opening balance & $£ 127 \mathrm{~s} 5 \mathrm{~d}$ & $£ 14$ s $9 d$ & $£ 13$ 19s 3d & $£ 70$ s $11 \mathrm{~d}$ \\
\hline Average deposit & $£ 107 \mathrm{~s} 8 \mathrm{~d}$ & $£ 12$ 1s $5 \mathrm{~d}$ & $£ 1118 \mathrm{~s} 10 \mathrm{~d}$ & $£ 517 \mathrm{~s} 3 \mathrm{~d}$ \\
\hline Average withdrawal & $£ 139 \mathrm{~s} 0 \mathrm{~d}$ & $£ 1616 \mathrm{~s} 8 \mathrm{~d}$ & $£ 168 \mathrm{~s} 6 \mathrm{~d}$ & $£ 20$ 4s 8d \\
\hline Total deposited & $£ 406 \mathrm{~s} 5 \mathrm{~d}$ & $£ 5618 \mathrm{~s} \mathrm{3d}$ & $£ 4513 \mathrm{~s} 1 \mathrm{~d}$ & $£ 20$ 5s $10 \mathrm{~d}$ \\
\hline Number of deposits & 7.79 & 6.54 & 9.46 & 5.18 \\
\hline Number of withdrawals & 5.24 & 5.79 & 5.50 & 2.18 \\
\hline Account duration & 4.98 years & 6.40 years & 4.87 years & 5.17 years \\
\hline A соиmulatin & $18.87 \%$ & $10.42 \%$ & $25.00 \%$ & $54.55 \%$ \\
\hline & $47.17 \%$ & $47.92 \%$ & $46.43 \%$ & $18.18 \%$ \\
\hline Draw down & $14.15 \%$ & $10.42 \%$ & $10.71 \%$ & $9.09 \%$ \\
\hline In and out & $19.81 \%$ & $31.25 \%$ & $17.86 \%$ & $18.18 \%$ \\
\hline
\end{tabular}

Note: Non-percentage figures are means. One depositor's location could not be identified. For some of the statistics above, there are not 194 observations (e.g. where an account was not closed). In the case of the four account types - accumulating, contingency, draw down and in and out - there is one account with just one deposit and therefore does not fit this classification. 
If we consider the first three columns, there is evidence that those living within half a mile of the bank have a smaller opening balance, make smaller deposits and withdrawals, and deposit less altogether than their counterparts. This may reflect a heightened propensity among small savers to engage in saving when a bank is more local. We see no obvious difference in the number of withdrawals, and for the remaining variables there is a lack of clear differentiation according to distance. Those outside our map area are somewhat anomalous, perhaps due to the small number of savers in this category.

To better understand the impact of distance, we consider its association with various transaction indicators through regression analysis. We use an OLS model and report the results in Table 5. The column headers indicate the respective dependent variables.

Table 5. Determinants of depositor behaviour

\begin{tabular}{|c|c|c|c|c|c|}
\hline & $\begin{array}{c}\text { (1) } \\
\text { Open. bal. }\end{array}$ & $\begin{array}{c}\text { (2) } \\
\text { Avg. dep. }\end{array}$ & $\begin{array}{c}\text { (3) } \\
\text { Tot. dep. }\end{array}$ & $\begin{array}{l}\text { (4) } \\
\text { No. of dep. }\end{array}$ & $\begin{array}{c}\text { (5) } \\
\text { Dep. to with. }\end{array}$ \\
\hline \multirow{2}{*}{$\begin{array}{l}\text { Adult } \\
\text { widow }\end{array}$} & 0.145 & 0.042 & -0.515 & $-3.523 *$ & $-1.154 *$ \\
\hline & $(0.495)$ & $(0.456)$ & $(0.416)$ & (1.997) & $(0.620)$ \\
\hline \multirow{2}{*}{$\begin{array}{l}\text { Adult } \\
\text { married }\end{array}$} & -0.472 & -0.408 & -0.382 & 0.253 & -0.212 \\
\hline & $(0.385)$ & $(0.366)$ & $(0.329)$ & $(2.265)$ & $(0.575)$ \\
\hline Adult female, single & $\begin{array}{c}-0.672 * * \\
(0.332)\end{array}$ & $\begin{array}{c}-0.723 * * \\
(0.299)\end{array}$ & $\begin{array}{c}-0.964 * * * \\
(0.289)\end{array}$ & $\begin{array}{c}-3.227 * * \\
(1.433)\end{array}$ & $\begin{array}{l}-0.156 \\
(0.519)\end{array}$ \\
\hline Child, male & $\begin{array}{c}-1.054 * * \\
(0.528)\end{array}$ & $\begin{array}{l}-0.677 \\
(0.467)\end{array}$ & $\begin{array}{l}-0.827 * \\
(0.429)\end{array}$ & $\begin{array}{c}3.804 \\
(5.998)\end{array}$ & $\begin{array}{l}-0.300 \\
(0.486)\end{array}$ \\
\hline Child, female & $\begin{array}{l}-0.910^{*} \\
(0.493)\end{array}$ & $\begin{array}{l}-0.841 * \\
(0.461)\end{array}$ & $\begin{array}{l}-0.918^{*} \\
(0.547)\end{array}$ & $\begin{array}{c}-0.822 \\
(1.959)\end{array}$ & $\begin{array}{c}0.974 \\
(0.789)\end{array}$ \\
\hline Joint & $\begin{array}{c}0.682 * * \\
(0.275)\end{array}$ & $\begin{array}{c}0.422 \\
(0.271)\end{array}$ & $\begin{array}{c}0.033 \\
(0.231)\end{array}$ & $\begin{array}{l}-2.611 \\
(2.103)\end{array}$ & $\begin{array}{c}-1.383 * * * \\
(0.509)\end{array}$ \\
\hline Trust & $\begin{array}{l}-0.093 \\
(0.368)\end{array}$ & $\begin{array}{l}-0.044 \\
(0.379)\end{array}$ & $\begin{array}{l}-0.567 \\
(0.351)\end{array}$ & $\begin{array}{c}-5.564 * * \\
(2.173)\end{array}$ & $\begin{array}{l}-0.248 \\
(0.979)\end{array}$ \\
\hline Within 0.5 mile & $\begin{array}{c}0.010 \\
(0.265)\end{array}$ & $\begin{array}{c}0.020 \\
(0.251)\end{array}$ & $\begin{array}{c}0.220 \\
(0.224)\end{array}$ & $\begin{array}{c}4.042 * * \\
(1.573)\end{array}$ & $\begin{array}{c}-1.128 * * \\
(0.569)\end{array}$ \\
\hline 0.5 to 1 mile away & $\begin{array}{l}-0.087 \\
(0.353)\end{array}$ & $\begin{array}{l}-0.011 \\
(0.332)\end{array}$ & $\begin{array}{c}0.185 \\
(0.365)\end{array}$ & $\begin{array}{c}3.458 * * \\
(1.358)\end{array}$ & $\begin{array}{l}-0.988 \\
(0.623)\end{array}$ \\
\hline Duration & $\begin{array}{c}0.023 \\
(0.087)\end{array}$ & $\begin{array}{l}-0.029 \\
(0.079)\end{array}$ & $\begin{array}{c}0.530 * * * \\
(0.096)\end{array}$ & $\begin{array}{c}4.264 * * * \\
(1.026)\end{array}$ & $\begin{array}{c}0.321 * * * \\
(0.115)\end{array}$ \\
\hline Max depositor & & & & $-3.726 * * *$ & $-1.068 * * *$ \\
\hline
\end{tabular}




\begin{tabular}{|c|c|c|c|c|c|}
\hline Constant & $\begin{array}{c}7.439 * * * \\
(0.697)\end{array}$ & $\begin{array}{c}7.671 * * * \\
(0.628)\end{array}$ & $\begin{array}{c}5.107 * * * \\
(0.756)\end{array}$ & $\begin{array}{c}(1.245) \\
-23.118 * * * \\
(7.302)\end{array}$ & $\begin{array}{c}(0.298) \\
1.246 \\
(0.818)\end{array}$ \\
\hline Observations & 184 & 184 & 184 & 184 & 184 \\
\hline R-squared & 0.096 & 0.070 & 0.302 & 0.305 & 0.157 \\
\hline
\end{tabular}

This analysis reveals that location is only statistically significant for two of the five transaction measures used, namely, the number of deposits and the ratio of deposits to withdrawals. We see that depositors who live within a half mile of the bank make a significantly higher number of deposits, which suggests that closer proximity increases transactional activity. Furthermore, those residing near the bank tend to have a significantly lower ratio of deposits to withdrawals, with the effect more obvious within a half mile radius.

Among the other significant variables, children and single women tend to have lower opening, average and total deposits, which is consistent with their lower earnings potential. Perhaps unsurprisingly, accounts which are open longer tend to deposit a larger value of deposits and have more deposits; they also have more deposits vis-à-vis withdrawals. We also see that max depositors tend to make significantly fewer deposits and have a lower deposit-to-withdrawal ratio - possibly reflecting the storage aspect mentioned previously. This pattern for max depositors is also evident for widows, because they are frequently max depositors. In addition, and consistent with the earlier summary statistics, joint accounts have a significantly lower deposit-to-withdrawal ratio - which likely relates to the relatively high number of withdrawals we see with such accounts that we attribute to smoothing of domestic expenditure in joint married accounts. Joint accounts also tend to have a relatively high opening balance. 


\section{Gaming the system}

Class of depositor analyses implicitly support the idea that evidence of middle-class depositors is evidence of, at best, an imposition on an institution set up to aid the poor to save and, at worst, deliberate misuse of the savings bank system. ${ }^{x l v}$ Had there been alternative institutions offering safe, convenient, and low/no cost banking options for those with middling amounts of savings then these criticisms would hold greater weight. Although it had long been the practice of Scottish banks to offer interest on deposits, as late as 1826 the Bank of England, the Bank of Ireland, and the private London banks still did not. The English joint-stock banks formed after that period did offer interest in order to compete for deposits, but the operation of jointstock banks were restricted within a 65 -mile radius of London until 1883 . $^{\text {xlvi }}$

The offer of interest on deposits by Scottish public and provincial banks was arguably a response to a capital-scarce economy, and the need to incentivise cash deposits. ${ }^{\text {xlvii }}$ Under the deposit receipt system, any sum over $£ 10$ could be placed with the bank, interest was paid annually, and when a withdrawal was made the existing receipt was voided and a new one added. By the 1840s, provincial banks were accepting deposits as low as $£ 2$. The deposit receipt was the main mechanism by which Scottish banks took deposits for a century and a half, and although they were also a feature of English country banks in the 19th century not all receipts attracted interest. ${ }^{\text {xlviii }}$ In such a restrictive environment, the English saver had few other options than the savings banks if they wished to deposit small (relative to the expectations of jointstock banks) amounts at interest.

Given the lack of options available to English middle-class savers of modest means, there is little to be gained by continuing to frame the presence of middle-class savers in English savings bank ledgers as problematic in and of itself. Instead, we have the data within the account ledgers to make better judgements about what behaviours were likely to represent an affront to 
the values of the system without being a substantial threat to its continuation. Problematic behaviours are, for obvious reasons, more likely to be found in the $£ 30$ opening deposit category and, in this section, we look in more detail at the accounts of these depositors.

We are confident that the 1830 cohort did not contain any depositors operating in the most obvious profit-seeking manner i.e. by depositing the maximum amounts allowed in their accounts in the shortest period of time with the aim of harvesting the interest payments. There is no instance amongst our 1830 sample in which a depositor opens an account with $£ 30$ and continues to deposit $£ 30$ each year until the limit is met. Although, Amelia Ford, a married woman, might have done so if her banking had not been cut short by death. She deposits the $£ 30$ limit for four consecutive years, and when her husband inherits her bank account he draws down from the balance. Twelve accounts are opened with the $£ 30$ maximum, attract interest for at least one year or part thereof, and closed without another deposit. The surprise, in terms of this group of depositors, is the frequency with which we see $£ 30$ deposited, the same amount withdrawn after qualifying for the payment of interest (which is left in the account), and then another $£ 30$ deposited in the next period. This strategy of keeping the total amount invested at around $£ 30$ rather than building up a large balance from which to harvest a small (but increasing) annual bonus would appear to confirm Fishlow's view that the 1828 deposit limits had done as intended, and removed the ability for interest payments to generate substantial profits for the depositor. ${ }^{\text {xlix }}$ Interest rates could still generate an advantage from a middling size of deposit in an individual account, but this was not an obvious route to a profit or income.

With the removal of the potential for a single account to generate an income stream via interest payments in 1828 , official attention then turned to the saver who might open multiple accounts to achieve the same end. Instead of being able to deposit $£ 300$ in an account, an individual wishing to gain the interest due on that amount would have to open ten separate $£ 30$ accounts. 
A change to the regulations in 1828 therefore tried to close this potential loophole by limiting individuals to one savings bank account in total, not one account in a single bank. With each savings bank being independent, and no capacity (or technology) that allowed cross-checking between banks the legislators were reliant on the deterrent power of advertised penalties. Each depositor was required to sign a declaration on opening an account that they had no other savings bank account. If discovered to be in possession of multiple accounts, the depositor would forfeit the balances in both or multiple accounts.

The system was - obviously - open to abuse, especially if you lived in a city or travelled frequently. The east end of London was sufficiently populous that a depositor opening a second account in a neighbouring district's savings bank could be reasonably confident of not being caught. The east end supported three savings banks in 1830. At the north-west extreme, about a 1.8 mile walk from the location of the Limehouse Savings Bank, was the Whitechapel Savings Bank. Its advertised interest rate was £3.5.2. (per £100) rather than the percentage interest rate we are more familiar with. The other bank that east end depositors could bank with in 1830, that of Poplar - less than a mile from Limehouse. Poplar was a much smaller establishment. Both Limehouse and Poplar offered interest rates of $£ 3.6 .8$, which removed any incentive to chase a higher interest rate a little way down the road. Furthermore, as a correspondent to the Morning Chronicle newspaper explained, why go to the bother of banking at a less convenient location when the simplest method of gaining advantage was simply to open an account in your own name and then hold more 'in trust' for fictitious individuals?

Some of the Limehouse sample year depositors chose to deposit at a bank that was not the closest to their residential address, yet do not appear to be trying to gain advantage. Amongst our 1951830 depositors there are three account holders who provide addresses almost in the shadow of the Whitechapel Savings Bank, and eight in total within half a mile of that 
institution, suggesting that some found the longer walk to Limehouse worthwhile for their own personal reasons. Ruth Noble, who resides at an address close to the Whitechapel bank, appears to bank in Limehouse on a weekly basis for two other servants as their trustee. We cannot see that she profits in either case. One trust is dissolved and is taken over by the trustee, and the other account lapses.

There are no obvious accounts that are based 'out of area' i.e. savers with addresses outside of the east end, that appear to be gaming the system. There is a single out of area account that opens with $£ 30$ (account no. 83), but it belongs to a married woman who gives her address as a naval ship, so she is probably banking the annual wages of her husband. Some of the out of area accounts are those of single women in service and we assume that they are banking close to their family home rather than their place of employment and residence. There is one account (no. 137) where $£ 12$ is banked per year for 4 years and then closed, but such regular deposits could easily be attributed to live-in employment elsewhere rather than indicating a second (prohibited) account.

Trust accounts are, however, problematic in this period. The 19th century saw the rapid spread of trusts. Formerly a legal mechanism used by the aristocracy to protect their wealth and land holdings through the male line, trusts were adopted by the middle class as a way of protecting more modest sums. Trusts required no registration and were considered a private arrangement, but their increasing use eventually required legal reform. ${ }^{\text {li }}$ Legislators moved more quickly in respect of trust accounts in savings banks than they did in regulating trusts elsewhere. The 1844 Savings Bank Act, the draft of which proposed to disallow accounts held in trust for fear that they were being used to evade the prohibition against multiple account holding, eventually passed with the new regulation that the beneficiary must sign with the trustee for withdrawals. ${ }^{\text {lii }}$ The percentage of trust accounts opened in Limehouse does drop noticeably in 1845. In 1843, 
35 trust accounts were opened and only six in 1846 but numbers recover later in the 1840s and trust accounts only start to disappear as a common account type in Limehouse in the second half of the $1850 \mathrm{~s}$.

The trust accounts opened by our 1830 savers have a higher than average deposit-to-withdrawal ratio i.e. suggestive of an accumulation strategy. Only four of the ten trust accounts opened in Limehouse in 1830 were held by parents for children, but all four are operated in a way that is consistent with storing family money - not always in large amounts - as opposed to instructing a child in the habits of thrift. Solomon Richards - in addition to his own account - opens one in trust for his daughter, makes two deposits in one year that total the maximum annual deposit of $£ 30$, and withdraws it after interest is paid. Mark Pillar opens an account in trust for his daughter Harriet, deposits $£ 3$ and withdraws it four years later. Henry Stacey opens a trust account for his daughter Mary, aged 6, which runs alongside his own account until he dies in 1854, when Mary would have been 30 . The presumption is that Henry operates the trust account without Mary's knowledge or benefit in order to supplement his own individual account.

An alternative to a trust account, should an individual wish to circumvent the one account rule, was to open an account in the name of your child/children and operate the child accounts in tandem with your own. Ledger data gives us the ability to compare linked family accounts for mirrored transactions. ${ }^{\text {liii }}$ Family accounts are largely dismissed in class of depositor analysis. Fishlow, for example, refers to savers without a listed occupation as ' ...otherwise unidentified women and children'. Parliamentary reports allocated wives to the husbands' occupation and put all minors in a separate category. ${ }^{\text {liv }}$ We establish family groups by recording linked accounts when we encounter them in the ledgers - these are typically savers with the same family name and residential address, and that we can see by the pattern of transactions are not 
operating their accounts independently. For example, we consider the accounts linked and potentially problematic if there are two child siblings who open accounts on the same day.

Our 1830 data contained 16 family groups, of which four comprised related adults. The remaining twelve family groups (representing 22 accounts) were linked via child siblings in the same household, or where there was clearly an adult parent with an account alongside one or more accounts opened in a child's name. Of those remaining twelve family groups, we identified two family groups where accounts were being operated independently and without suspicion of being puppet accounts. In the ten remaining family groups, the amounts deposited and withdrawn and the dates these transactions were made were identical, or very similar across the accounts within the family. We interpret this behaviour as adults using child accounts as cover for multiple account holding.

In summary, out of the 195 accounts examined in the 1830 cohort we flagged 20 that had transaction records that were suggestive of accounts that were operating outside of the spirit (and letter) of the regulations. ${ }^{\mathrm{lv}}$ If we assume that the ostensible owners of the puppet accounts - the children of adult savers - are not aware of the existence of these accounts, then the number of suspected individuals gaming the system falls to six in total. Only two of these savers kept the suspect accounts open for longer than a year. The majority of the suspect accounts were in existence for very short periods of time, suggesting a need to keep surplus resource safe until it was needed or re-invested elsewhere. Of course, there may be more individuals gaming the system than we identified who are hiding in plain sight and whose transaction history is more subtle than that of the account holders we identify in Table 6. It is equally the case that some of the individuals we have identified are possibly suspected without cause. For example, it is possible that Mary Stacey has a disability that prevented her from banking, and that holding a trust account for her into adulthood is defensible. But our view is that a circa $10 \%$ rate in respect 
of suspect accounts should not be the basis of a moral panic or grounds for dismissing the undoubted benefits that the savings bank provided to its depositors.

\section{Table 6. Flagged accounts}

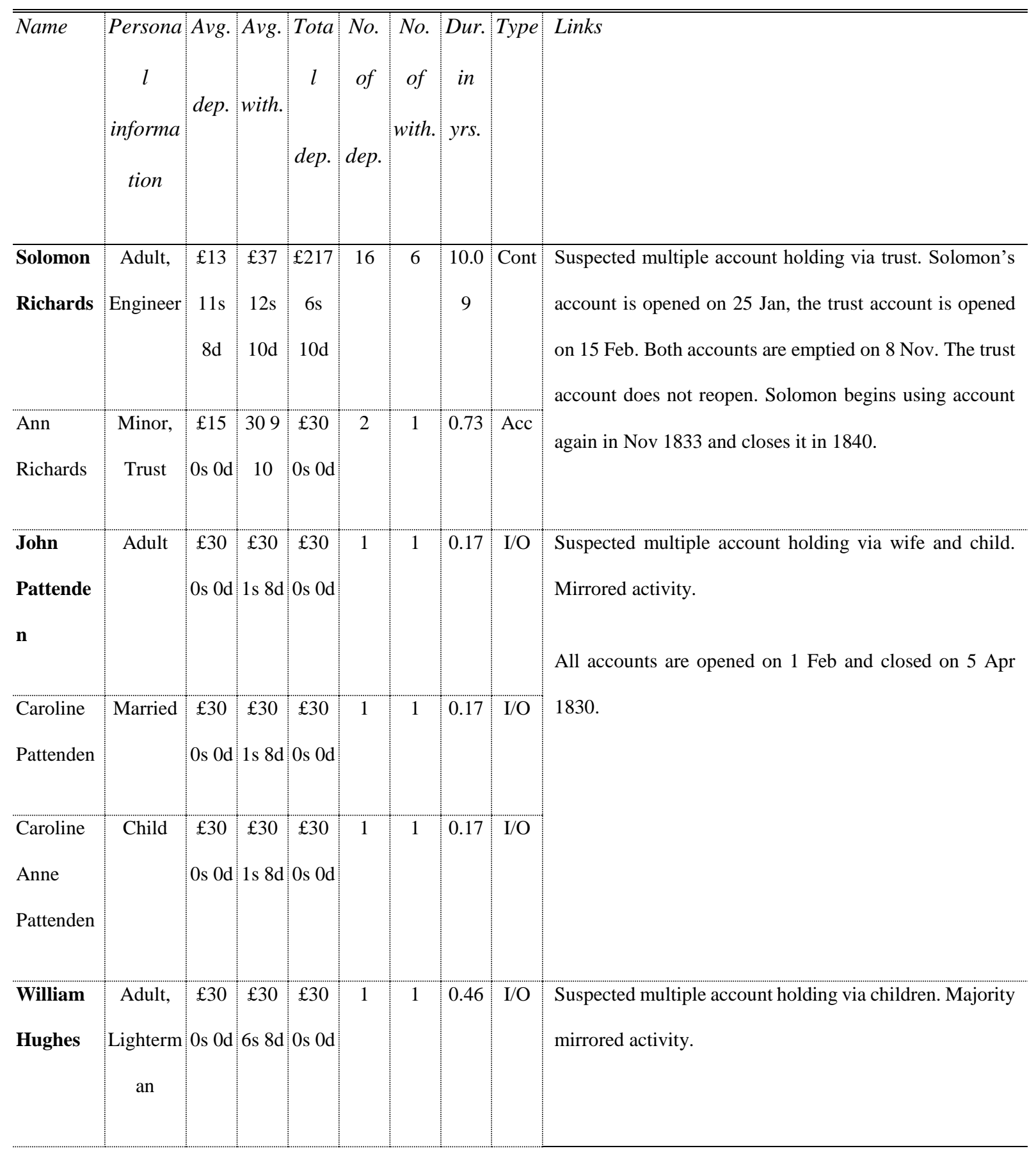




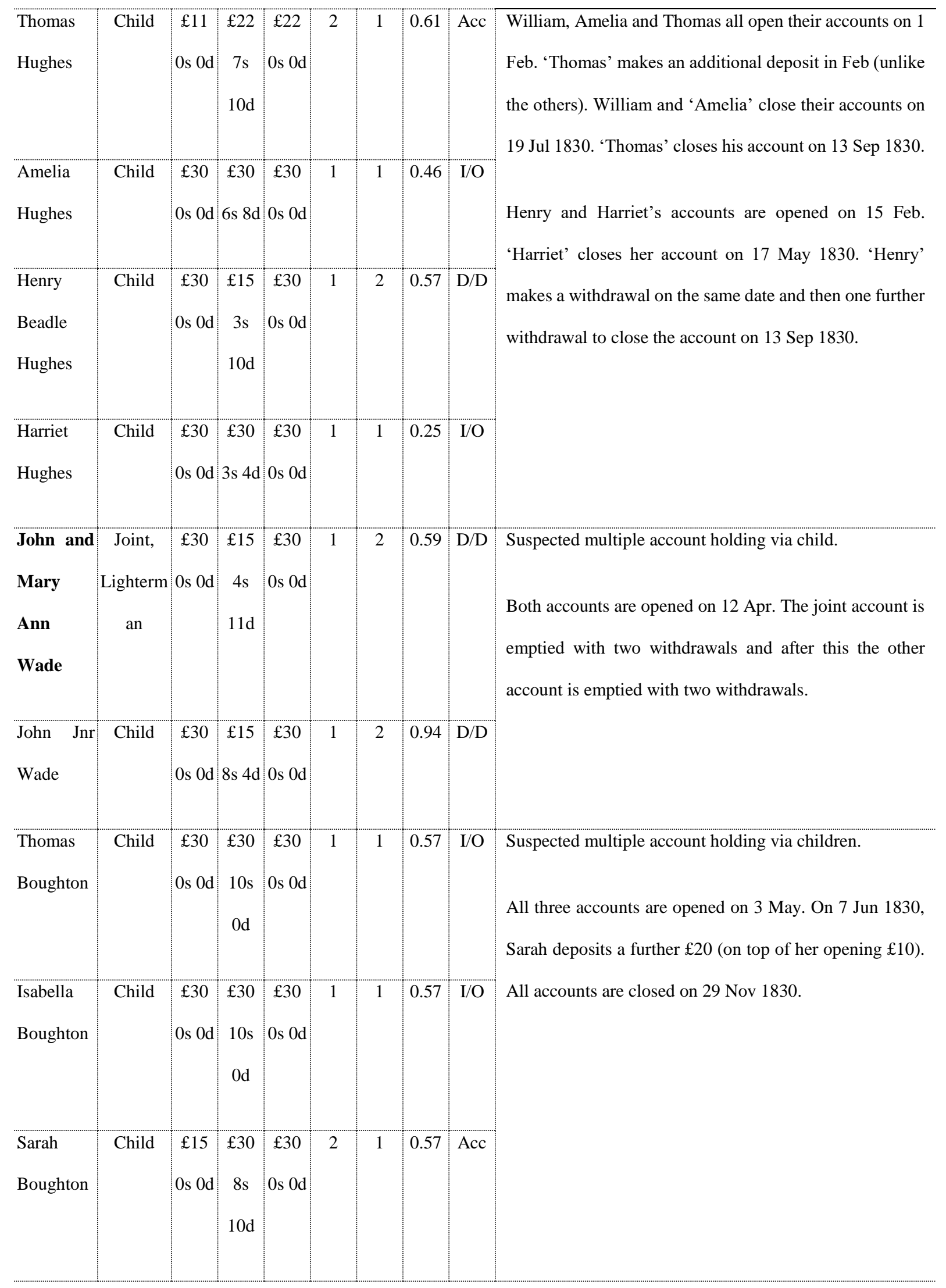




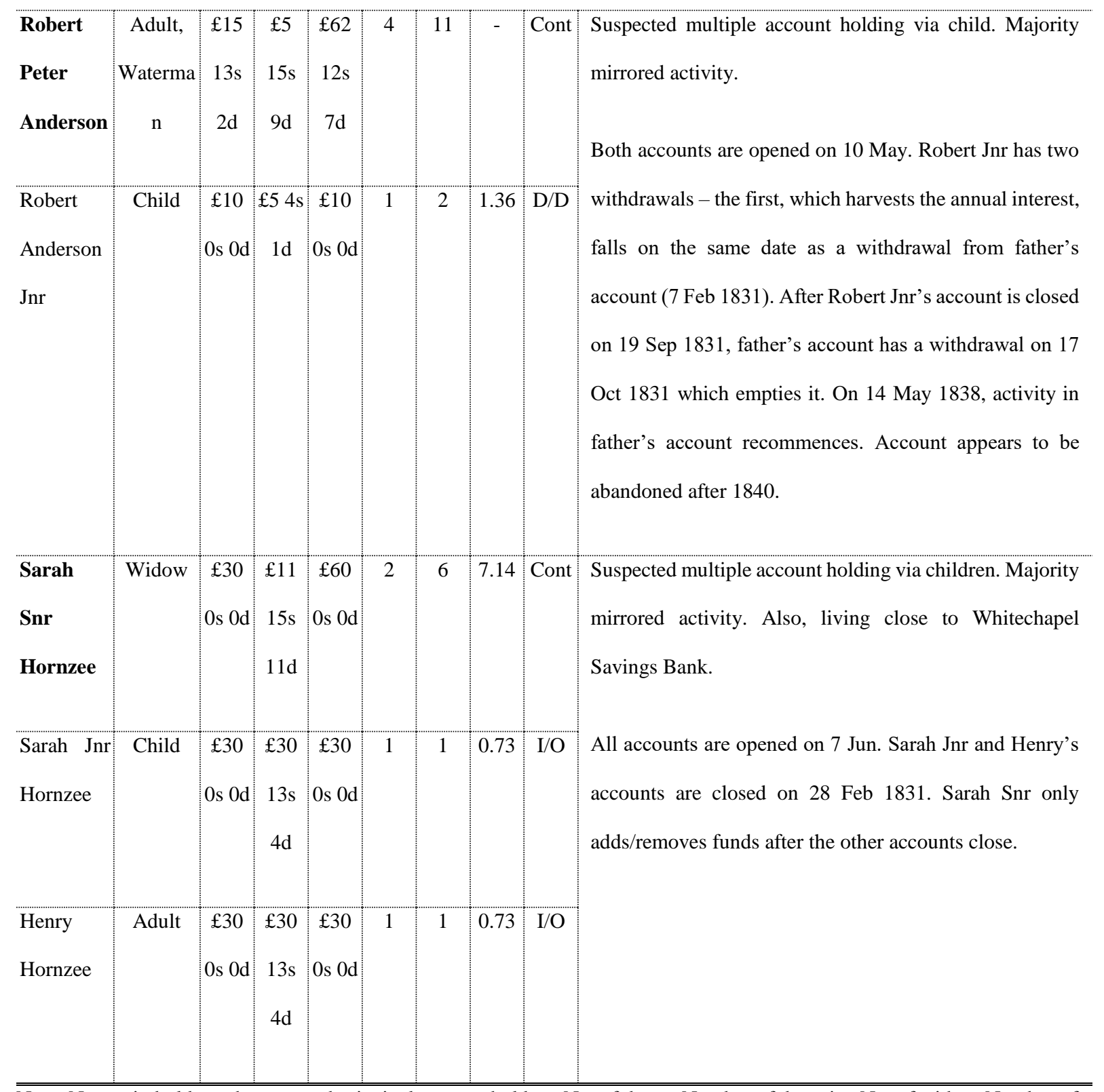

Note: Names in bold are the assumed principal account holders. No. of dep. = Number of deposits; No. of with. = Number of withdrawals; Total dep. $=$ Total deposited; Avg. dep. = Average deposit; Avg. with. $=$ Average withdrawal; Dur. in years. $=$ Duration in years; Type $=$ Account type; $\mathrm{I} / \mathrm{O}=\mathrm{In}$ and out Acc $=$ Accumulating; $\mathrm{D} / \mathrm{D}=$ Draw down Cont $=$ Contingenc 


\section{Conclusions}

In this paper, we have shown the value provided by transaction data in the study of British savings banks in the 19th century. Although the data collection from hand-written ledgers is time-consuming, and therefore not without cost, there are significant benefits in adopting such an approach. Transaction data allows us to - finally - move away from occupational class as a way of recording and comparing British savings bank depositors. Occupational class, and descriptions of savers who are not listed according to their employment - such as women and children, differ widely between institutions. They are an unsafe basis for comparisons of savers across institutions, or across time periods, or nations. Using transactions to characterise saver behaviour will enable more intranational and international comparative work, especially if researchers can use a common framework of account categories and observation types e.g. opening deposits.

In respect of our working hypotheses for the 1830 cohort research, we find that opening deposit data is indicative of future savings behaviour. The data suggests that where the opening deposit is small it is more likely to lead to a savings approach to the account. In contrast, where the opening deposit is at the annual deposit limit of $£ 30$ the account is more likely to be used for parking or storing money. Opening deposit may also indicate broad differences in motivation to have an account, with those opened at $£ 30$ arguably more strategic in their aims, particularly in the case of child accounts.

Our analysis of the 1830 cohort also reinforces the finding of contemporary microfinance and savings theory that proximity to banks matters. Savers in close proximity to the bank in our sample tend to make smaller transactions. This may reflect the greater uptake of savings services among less affluent clientele when a bank is closer to them. There is also some 
evidence that those living closest to the bank make more deposits, which again reflects locational convenience.

Finally, we examined the transactions in order to identify accounts that were potentially gaming the savings bank system. The presence of comparatively high numbers of middle-class savers, compared to those using savings banks in Ireland and Scotland, has - since the creation of the banks in the early 19th century - fuelled the suspicion that a large number of depositors were exploiting the generous interest rates offered. Occupational class analyses of savings banks have continued this narrative despite the lack of alternative low-cost or interest-bearing deposit opportunities for those with small to middling amounts of money to save. The suspicion remained in the literature that English savings banks were prey to organised middle-class rentier behaviour. Our cohort transaction analysis has revealed a low level of system gaming affecting approximately $10 \%$ of the accounts opened in 1830 . The most common strategy appeared to be opening an account(s) on behalf of your own children and using that account for short-term storage of money. There did not appear to be widespread rent-seeking behaviour in regard to interest payments. Most of the accounts that show evidence of being operated by parents as puppet accounts are open for very short periods of time - typically 6 months - and do not generate interest payments of the size that make them viable sources of additional income.

Indeed, when we look at the transactions of the 1830 cohort overall, they tell a familiar and oddly comforting and human collective tale of short-term accumulations, long gaps between deposits, and a distinct lack of success in the long term. An analysis of the cohort transactions shows us the limitations of the contemporaneous debates about access to financial institutions. Neither the view that savings banks would lift the working class out of poverty through habits of thrift, nor the belief that savings banks were routinely exploited by the middle classes, is 
supported by the data. Rather, the savers at the Limehouse Savings Bank appear to be adapting its financial services to suit their individual needs. These behaviours were not those espoused by legislators, but nonetheless were valid in the absence of readily available alternatives. Examining transaction data enables us to better position English and Welsh savings banks within the history of retail banking and humanise the longitudinal behaviours of their diverse clienteles who used them for all their intents and purposes.

\section{References}

\section{Books}

Checkland, Sydney. Scottish Banking: A History, 1695-1973. Glasgow: Collins, 1975.

Garon, Sheldon. Beyond Our Means: Why America Spends While the World Saves. Princeton, NJ: Princeton University Press, 2012.

Gommersall, Meg. Working-Class Girls in Nineteenth-Century England: Life, Work and Schooling. London: Palgrave Macmillan UK, 1997.

Goose, Nigel, and Katrina Honeyman. Childhood and Child Labour in Industrial England: Diversity and Agency, 1750-1914. Farnham: Ashgate, 2013.

Horne, H. Oliver. A History of Savings Banks. Oxford: Oxford University Press, 1947.

Johnson, Paul. Saving and Spending: The Working-Class Economy in Britain, 1870-1939. Oxford: Clarendon Press, 1985. 
Munn, Charles W. The Scottish Provincial Banking Companies, 1747-1864. Edinburgh: John Donald Publishers Ltd, 1980.

Pollard, Sidney. A History of Labour in Sheffield. Liverpool: Liverpool University Press, 1959.

Pratt, John T., The History of Savings Banks in England, Wales, and Ireland: with the Period of the Establishment of Each Institution, the Place Where it is Held, the Days and Hours When Open, the Rate of Interest Payable, and the Number of Depositors, Classed According to the Latest Official Returns; \&c. \&c. \&c.. C. J. G. \& F. Rivington: London, 1830.

White, Jerry. London in the Nineteenth Century: A Human Awful Wonder of God. London: Bodley Head, 2011.

\section{Articles, Chapters in Books, Dissertations, and Papers}

Aidoo-Mensah, Daniel. "Savings and Income Relationships among Households: A Review of the Literature." Agricultural Socio-Economics Journal 18, no. 3 (2018): 133-143.

Allen, Robert C., Jean-Pascal Bassino, Debin Ma, Christine Moll-Murata, and Jan Luiten van Zanden. "Wages, Prices, and Living Standards in China, 1738-1925: In Comparison with Europe, Japan, and India.” Economic History Review 64, no. S1 (2011): 8-38.

Alter, George, Claudia Goldin, and Elyce Rotella. "The Savings of Ordinary Americans: The Philadelphia Saving Fund Society in the Mid-Nineteenth Century." Journal of Economic History 54, no. 4 (1994): 735-767.

Anbinder, Tyler, Cormac Ó Gráda, and Simone A. Wegge. "Networks and Opportunities: A Digital History of Ireland's Great Famine Refugees in New York." American Historical Review 124, no. 5 (2019): 1591-1629. 
Browning, Martin, and Thomas F. Crossley. "The Life-Cycle Model of Consumption and Saving." Journal of Economic Perspectives 15, no. 3 (2001): 3-22.

Clark, Gregory, "The Condition of the Working Class in England, 1209-2004." Journal of Political Economy 113, no. 6 (2005): 1307-1340.

Cunningham, Hugh. "How Many Children Were 'Unemployed' in Eighteenth- and Nineteenth-Century England?: Reply.” Past and Present, no. 187 (2005): 203-215.

Fishlow, Albert. “The Trustee Savings Banks, 1817-1861.” Journal of Economic History 21, no. 1 (1961): 26-40.

Folbre, Nancy. "The Unproductive Housewife: Her Evolution in Nineteenth-Century Economic Thought.” Signs: Journal of Women in Culture and Society 16, no. 3 (1991): 463484.

Humphries, Jane, and Jacob Weisdorf. "The Wages of Women in England, 1260-1850." Journal of Economic History 75, no. 2 (2015): 405-447.

Kirby, Peter. "A Brief Statistical Sketch of the Child Labour Market in Mid-NineteenthCentury London." Continuity and Change 20, no. 2 (2005): 229-245.

Lawson, Zoe. "Save the Pennies! Savings Banks and the Working Class in Mid NineteenthCentury Lancashire.” Local Historian 35, no. 3 (2005): 168-183.

Lemire, Beverly. "Gender, Savings Culture \& Provident Consumerism - Patterns, Practice \& Research Opportunities." Unpublished Workshop Paper given at the Workshop on WorkingClass Women's Savings Strategies, 1780-2008, York, 2008. 
Lloyd-Jones, Roger, and Myrddin J. Lewis. Small Savers in the Late Victorian Period; A Business Data Base of the Sheffield Savings Bank c. 1861-1901. Leicester: Perpetuity Press, 1991.

Maltby, Josephine. “'The Wife's Administration of the Earnings'? Working-Class Women and Savings in the Mid-Nineteenth century." Continuity and Change 26, no.2 (2011): 187-217.

. “To Bind the Humbler to the More Influential and Wealthy Classes'. Reporting by Savings Banks in Nineteenth Century Britain.” Accounting History Review 22, no. 3 (2012): $199-225$.

McLaughlin, Eoin J. “Microfinance Institutions in Nineteenth Century Ireland.” $\mathrm{PhD}$ Thesis, National University of Ireland Maynooth, 2009.

Ó Gráda, Cormac. "Savings Banks as an Institutional Import: The Case of Nineteenth-Century Ireland.” Financial History Review 10, no. 1 (2003): 31-55.

. "The Early History of Irish Savings Banks.” UCD Centre for Economic Research Working Paper Series, WP08/04 (February, 2008). Available at: https://researchrepository .ucd.ie/bitstream/10197/494/3/ogradac_workpap_010.pdf (last accessed: 15 September 2019).

Olmstead, Alan L. "New York City Mutual Savings Banks in the Ante-Bellum Years: A Dissertation Summary.” Journal of Economic History 31, no. 1 (1971): 272-275.

Payne, Peter L. “The Savings Bank of Glasgow, 1863-1914.” In Studies in Scottish Business History, edited by Peter L. Payne, 152-186. London: Routledge, 1967.

Perriton, Linda. "Depositor Trends in the Limehouse Savings Bank, London, 1830-1876." World Savings Bank Institute (2012). Available at: https://www.wsbi-esbg.org /SiteCollectionDocuments/perriton.pdf (last accessed: 15 September 2019). 
Perriton, Linda, and Josephine Maltby. "Savings Banks in England and Wales in the Nineteenth Century: A New Insight into Individual Spending and Savings.” Business Archives, 105 (2012): 47-64.

"Working-Class Households and Savings in England, 1850-1880." Enterprise and Society 16, no. 2 (2015): 413-445.

Pollock, Gordon D. "Aspects of Thrift in East End Glasgow: New Accounts at the Bridgeton Cross Branch of the Savings Bank of Glasgow, 1881.” International Review of Scottish Studies 32, (2007): 117-148.

Rodriguez, Meyer. "The Analysis of Saving Behavior: The Case of Rural Households in the Philippines.” Philippine Institute for Development Studies Working Paper Series, 8820, 1988. Available at: https://opendocs.ids.ac.uk/opendocs/handle/123456789/3829 (last accessed: 15 September 2019).

Ross, Duncan M. “'Penny Banks' in Glasgow, 1850-1914.” Financial History Review 9, no.1 (2002): 21-39.

_ "Savings Bank Depositors in a Crisis: Glasgow 1847 and 1857." Financial History Review 20, no. 2 (2013): 183-208.

Stebbings, Chantal. The Private Trustee in Victorian England. Cambridge: Cambridge University Press, 2002.

Turvey, Ralph. (2010) “The Cost of Living in London, 1740-1834." London School of Economics Economic History Department Working Papers, No. 147/10 (October, 2010). Available at: http://eprints.lse.ac.uk/29960/1/WP147.pdf (last accessed: 12 March 2020). 
Vechbanyongratana, Jessica. "Personal Savings in Nineteenth-Century America." Journal of Economic History 70, no. 2 (2010): 499.

Venables, Anthony J., and Samuel E. Wills. "Resource Funds: Stabilising, Parking, and Intergenerational Transfer.” Journal of African Economies 25, no. suppl_2 (2016): ii20-ii40.

Wadhwani, Rohit Daniel. "Banking from the Bottom Up: The Case of Migrant Savers at the Philadelphia Saving Fund Society during the Late Nineteenth Century." Financial History Review 9, no. 1 (2002): 41-63.

Wegge, Simone A., Tyler Anbinder, and Cormac Ó Gráda. "Immigrants and Savers: A Rich New Database on the Irish in 1850s New York." Historical Methods: A Journal of Quantitative and Interdisciplinary History 50, no. 3 (2017): 144-155.

Williams, Samantha. "The Maintenance of Bastard Children in London, 1790-1834." Economic History Review 69, no. 3 (2016): 945-971.

Wotherspoon, Gary. "Savings Banks and Social Policy in New South Wales 1832-71." Australian Economic History Review 18, no. 2 (1978): 141-163.

\section{Legislative and Parliamentary Papers}

BPP, (British Parliamentary Paper), Savings Banks, [HOC 905] (1850).

BPP, Post-Office Savings Banks, [HOC 262] (1861) 


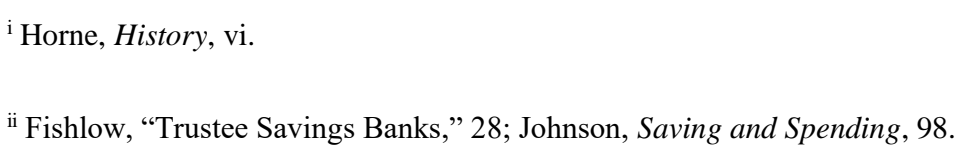

iii Although this is largely due to the lack of ledger data use in studies of English and Welsh savings banks.

iv E.g. Olmstead, "New York"; Wegge, Anbinder, and Ó Gráda, "Immigrants and Savers"; Anbinder, Ó Gráda, and Wegge, "Networks and Opportunities"; Vechbanyongratana, "Personal Savings"; Alter, Goldin, and Rotella, “Ordinary Americans"; Wadhwani, "Bottom Up".

v Ó Gráda, “Savings Banks,” 41-42; Ross, “Savings Bank Depositors,” 195-197.

vi The study of economics has a life-cycle framework within which models of saving are developed. The framework assumes that agents make sequential decisions about income and saving to achieve a coherent goal in terms of the availability of funds in retirement. However, the life-cycle framework has difficulty in accounting for heterogeneity of wealth and approaches to retirement income (see Browning and Crossley, "Life-Cycle Model," 2, 21). In a challenge to life-cycle approaches, some economists prefer an explanation where households' propensity to save in poorer households is higher from transitory income - the income that comes in spurts and is experienced as a 'bonus' above expected income (Rodriguez, "Saving Behavior," 8).

vii The first savings bank in the UK is usually considered to be that created in Ruthwell, Scotland by the Reverend Henry Duncan in 1810. The idea spread to other parts of the UK and many similar institutions were formed. With the passing of the legislation in 1817 promoting the establishment of savings banks and the mechanism for their funds to be invested in government bonds, existing savings institutes and societies transferred their holdings to Consols and fell under the regulatory framework set out in the 1817 Act, and subsequent amendments. Limehouse was one of these institutions that existed as a provident society prior to the legislation but became a savings bank after 1817.

viii See accounts of these criticisms in Fishlow, "Trustee Savings Banks,” 38; Ó Gráda, "Early History,” 11-12; McLaughlin, “Microfinance Institutions,” 279-280; Maltby, “Wife’s Administration,” 194; Maltby, “To Bind the Humbler,” 207.

ix Maltby, “To Bind the Humbler,” 207.

x Maltby, "To Bind the Humbler," 202-203.

xi Maltby, “To Bind the Humbler," 207-212.

xii Maltby, "To Bind the Humbler," 215-216.

xiii Folbre, "Unproductive Housewife," 464. 
xiv Fishlow, "Trustee Savings Banks,” 28, 31; Johnson, Saving and Spending, 94.

xv Fishlow, “Trustee Savings Banks,” 28.

xvi E.g. Alter, Goldin, and Rotella, "Ordinary Americans"; Wadhwani, "Bottom Up”; Ross, "Savings Bank Depositors," 201203.

xvii Payne, “Savings Bank of Glasgow," 163.

xviii Perriton and Maltby, "Working-Class Households", 424.

xix White, London, 109-110. Those who are not familiar with the geography of London may, nonetheless, be familiar with a map of the area used as the title sequence of the popular and long-running British TV programme EastEnders.

${ }^{x x}$ Pratt, History.

xxi Savings banks did not allow accounts to remain open with a zero balance. Upon re-opening, account transactions were continued under their original ledger entries if they were done so in the life of the ledger (in practice within 2-5 years of closure). We note where accounts are subject to closure and re-opening but, for the purposes of analysis, treat the account duration as dating from the first deposit and last withdrawal as if two or three sequential accounts were one account.

xxii We used a copy of Cross's 1851 map of London to locate the street addresses that depositors registered at to plot the distance to the bank. The relevant panels (14-16 of Cross's map) were sourced from: http://london1851.com/ on the free-toview MAPCO site http://mapco.net/index.htm

xxiii Alter, Goldin, and Rotella, "Ordinary Americans," 749. The aims of our paper are broadly in sympathy with "Ordinary Americans", in that both papers are concerned with the microeconomics of ordinary, small-amount savers who were the majority of English and Welsh savers in the 19th century and who had few safe methods of savings. Where the two papers differ is in presentation of data - "Ordinary Americans" takes the length of time the account is open as the primary analytical focus, treats the opening deposit as non-typical of subsequent behaviour, and has greater access - because of the later date it covers - to age and nationality data.

xxiv Pollock, “Aspects of Thrift,” 124.

${ }^{\mathrm{xxv}}$ For an example of the exploitation of trusts in this respect, see The Morning Chronicle, February 28, 1843, "Savings Banks No Test of the Condition of the Working Classes."

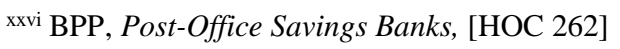

xxvii Aidoo-Mensah, "Savings and income," 140.

xxviii Fishlow, “Trustee Savings Banks,” 31.

xxix Where alternatives existed, as in Scotland in the same period, the savings banks do not have to defend themselves from the 
same criticisms. Ireland's savings bank behaviour is considered to have reflected the situation on the ground, with the smaller pool of more affluent savers not making a substantial difference to the overall accounts (see Ó Gráda, "Early History"; McLaughlin, "Microfinance Institutions"). But the lack of exploitative middle-class use of Scottish savings banks is attributed to the policies of its provincial banks in this period. Scottish public and provincial banks welcomed the middling sort of saver - allowing smaller minimum deposits and encouraging depositors into their institutions with good interest rates.

xxx Perriton, "Depositor trends," 22.

xxxi E.g. Cunningham, "How Many Children”; Gommersall, Working-Class Girls; Goose and Honeyman, Childhood; Kirby, "Brief Statistical Sketch."

xxxii The question of how the modern reader can value the amounts deposited is a somewhat fraught one. Historical wage data, where London is often accepted as an outlier, and retail price index series are constructed to try and capture long-run changes. As a result, it is difficult to establish the buying power of $£ 1$ in London in 1830 . Turvey, "Cost of Living," 3,14 , suggests that it is useful to look at children's living costs in the period as they are accessible in charitable relief records. His calculation is that the cost of food and basic provisions (e.g. clothing, shoes) for a boy in London circa 1830 was $£ 112$ s per annum. Williams, "Bastard Children," 961, takes a similar approach in studying the child support payments provided by the fathers of illegitimate children to the parish. Her data suggests a weekly maintenance amount of between $2 \mathrm{~s} 6 \mathrm{~d}$ and $4 \mathrm{~s}$ per week, which at the lower contribution rate would be approximately $£ 74$ s per annum. Clark, "Condition," 1325, places the average daily pay of an unskilled builder's labourer/helper in London in the 1830s at 28d per day, which would mean a deposit of $£ 1$ would represent approximately 8.5 days' work. Humphries and Weisdorf, "Women's Wages," 432, suggests that the daily rate for a waged adult woman in the same period was $13 \mathrm{~d}$ per day, which would mean a deposit of $£ 1$ represented 18 days’ work.

xxxiii Adult women were normally classified in the acccount ledgers according to marital status, but there are exceptions to this e.g. Mary Rothon, who is listed as a sweep. Where women are listed as servants we have assumed they are single, reasoning that the incidence of married women in residential service was small. However, the decision as to whether an account holder was a child (i.e. minor) or not is complicated by the judgement as to working age. The assumption from our sample is that adult status was conferred when young men reported being in work, regardless of their chronological age - which may have typically been about the age of 15 . Young women are characterised by their occupation (i.e. servant), with no occupation, or - in six cases - by being designated as either single or a spinster.

xxxiv Sarah Hornzee's behaviour is also interesting in terms of her residential location and use of child accounts. Her case also appears in the section on gaming the system.

xxxv Alter, Goldin, and Rotella, “Ordinary Americans,” 756.

xxxvi Perriton and Maltby, "Working-class households," 428.

xxxvii Perriton and Maltby, "Working-class households," 437. 
xxxviii We note the one outlier account - a multiple saver account opened with $£ 60$, which we assume is the result of a clerk assuming the $£ 30$ rule applied to each of the joint account holders, and not the account. Alter, Goldin, and Rotella, "Ordinary Americans," 750 , note that the median opening deposit for all accounts was $\$ 50$ (which they calculated was $20 \%$ of the annual labourer's wage in that period). Using the labourer wage figures from Clark, "Condition," 1325, and the calculation of the average working year of 260 days from Humphries and Weisdorf, "Women's Wages," 406, the median for deposits in the small saver and intermediate savings categories in our sample (i.e. we excluded the $£ 30$ opening deposit accounts) was $£ 10$. This median opening deposit represents $33 \%$ of a male labourer's wage in the 1830 s, and $71 \%$ of a woman's wage.

Alter, Goldin, and Rotella treat the opening deposit as atypical, whereas our analysis suggests it is indicative of future savings behaviour. Subsequent studies of the same institution i.e. Wadwhani, "Bottom up," 47, suggested that the relatively low spread of opening deposits in the Philadelphia institution may be a consequence of the profile of account holders - a substantial number of depositors were internal migrants or immigrants depositing cash needed to establish themselves in a new location. Whereas urban growth, rather than immigration, explains the movement of individuals and their families into the catchment area of Limehouse Savings Bank.

xxxix We include here the one account opened with $£ 60$.

${ }^{\mathrm{xl}}$ To illustrate the point we made earlier about common occupations across analytical categories we note the following occupations of adult males in our sample, and disaggregated adult female groups, in the three opening deposit categories:

$\leq £ 2$ : Engineer (1), Mariner (1), Shipwright (2), Timber Merchant (1), Waterman (1), No occupation listed (4), Widow (2), Married (10), Single (14);

$>£ 2$ and <£30: Baker (1), Carpenter (1), Cowkeeper (1), Engineer (4), Labourer (4), Lighterman (1), Mariner (3), Police Officer (1), Ropemaker (1), Sawyer (1), Shipwright (3), Shopkeeper (2), Sugar Baker (2), Tinman (1), No occupation listed (7), Widow (3), Married (17), Single (16);

£30: Cooper (1), Engineer (1), Lighterman (1), Mariner (2), Shipwright (2), Tinman (1), Waterman (1), No occupation listed (5), Widow (4), Married (6), Single (2).

xli The storage, or "parking', of money is a strategy available to national economies (see Venables and Wills, "Resource Funds," ii31). However, it was also a strategy available to individual families in the 19th century. 'Having a safe place to deposit', according to the testimony of the manager of the Croydon Savings Bank, 'was the chief inducement' to save with 'the amount of interest for the most part forms but a secondary consideration' being much more important to the savings bank customer than interest rates. (See BPP, Savings Banks, [HOC 905]).

xlii Perriton and Maltby, "Working-class households," 424-425.

xliii We consider this issue when we discuss linked accounts later in the paper.

xliv We are unable to allocate one depositor to these locations. 
xlv 'Gratifying as it might have been that [the middle class] found the bank a useful receptacle for their savings, they were not primarily the class of people that the bank had been founded to serve' (Wotherspoon, "Savings Banks," 159).

${ }^{x l v i}$ Checkland, Scottish Banking, 384.

xlvii Munn, Scottish Provincial Banking, 147-148.

xlviii Checkland, Scottish Banking, 189.

xlix Fishlow, "Trustee Savings Banks," 31.

${ }^{1}$ The Morning Chronicle, February 28, 1843, "Savings Banks No Test of the Condition of the Working Classes."

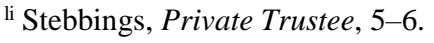

lii Horne, History, 106.

liii At present, with a single sample point, we can only link depositors together if they open their account in the same year but the ability to establish family savings groups will increase with the sample size.

liv Fishlow, "Trustee Savings Banks,” 28.

lv These were accounts opened by an adult(s) on the same day as those for children in the same family, and which showed similar transaction patterns e.g. accounts having money withdrawn/deposited on the same day and closed simultaneously. 